University of Miami Law School

University of Miami School of Law Institutional Repository

2004

Pari Passu and a Distressed Sovereign's Rational Choices

William Wilson Bratton

Follow this and additional works at: https://repository.law.miami.edu/fac_articles

Part of the Law Commons 


\title{
PARI PASSU AND A DISTRESSED SOVEREIGN'S RATIONAL CHOICES
}

\author{
William W. Bratton*
}

\section{INTRODUCTION}

In 1983, the Republic of Peru guaranteed foreign bank borrowings of Banco de la Nacion and Banco Popular de Peru. Some years later, Peru and the two banks defaulted on this and much other external debt. Some years later still, in 1996, most of Peru's bank lenders agreed to a composition. Under this, the 1983 instruments were exchanged for "Brady Bonds," with the bonds either stating a reduced principal amount or paying a lower rate of interest.'

Elliott Associates, a holder of the 1983 debt, held out from the composition, refusing to participate. Elliott, a "vulture fund" specializing in obligations of distressed firms and countries, ${ }^{2}$ had purchased $\$ 20.7$ million face amount of Peru's $1983 \mathrm{debt}$ at the discounted price of $\$ 11.4$ million from two international banks while the restructuring negotiations were ongoing. ${ }^{3}$ Elliott brought an action to enforce the debt at face value in the Southern District of New York, a focal point venue in the emerging world of sovereign debt enforcement. Legal recourse against defaulting sovereigns is available in the

* Professor of Law, Georgetown University Law Center. This project began in conversations with Mitu Gulati, who bears no responsibility whatsoever for the assertions made herein. My thanks to David Carlson for his excellent comments.

1 Declaration of Professor Andreas F. Lowenfeld, TII 1, 8, Elliott Assocs., L.P. v. Banco de la Nacion (S.D.N.Y. Aug. 31, 2000) (96 Civ. 7916) [hereinafter Lowenfeld Declaration].

2 These hedge funds typically purchase the debt of companies and countries that are in financial distress and, therefore, hold debt that is trading at a deep discount. Although even the Institute of International Finance-the global association of financial institutions-has publicly called for a targeted legal strategy to counter the supposedly disruptive activities of vulture funds in the context of sovereign restructurings, these funds are not without their supporters. See John Dizard, A Bankrupt Solution to Sovereign Debt, FIN. TIMES, Jan. 18, 2002, at 24 (arguing that there is nothing problematic about a vulture fund that purchases sovereign debt at a deep discount and then sues to be paid in full); Vulture Hunt, FIN. TIMES, May 7, 2002, at 20 (arguing that vulture funds serve to provide much needed liquidity in the markets for distressed sovereign debt). From a supportive point of view, Elliott's enforcement action respecting Peruvian debt can be analogized to enforcement of the securities laws by the plaintiff's bar.

3 Elliott Assocs., L.P. v. Banco de la Nacion, 194 F.3d 363, 366-67 (2d Cir. 1999). 
courts of countries like the United States and the United Kingdom, ${ }^{4}$ even as sovereign immunity prevents direct enforcement of sovereign obligations in the obligors' own courts. Elliott emerged from the Southern District with a judgment of $\$ 55,660,831.56 .^{5}$ Unfortunately for sovereign creditors in Elliott's position, such judgments have value only to the extent the creditor can identify property of the defaulting sovereign in the jurisdiction of the judgment or another jurisdiction willing to levy execution. Sovereigns in default rarely leave valuables lying around subject to attachment in creditor-friendly jurisdictions.

Elliott beat the odds and got paid. It relied on the 1983 debt contract's pari passu clause, which provided, "The obligations of the Guarantor hereunder do rank and will rank at least pari passu in priority of payment with all other External Indebtedness of the Guarantor, and interest thereon." Elliott took the clause to Brussels, the home of Euroclear, a clearing house through which funds from abroad enter the European banking system. Peru was about to dispatch a large payment on its Brady Bonds to European holders via Euroclear. Elliott, in an ex parte proceeding, persuaded the Belgian courts to block the payment on the ground that the pari passu clause gave the holders of the 1983 debt the right to participate pro rata in Peru's payments to other foreign creditors.' Peru, not wishing to default on its Brady Bonds, paid Elliott in full. ${ }^{8}$ Since then, vulture investors have successfully repeated the tactic, ${ }^{9}$ with mixed results. ${ }^{10}$

4 The statutes that relax the traditional sovereign immunity barrier are the Foreign Sovereign Immunities Act, 28 U.S.C. $\$ \S 1330,1332$ (a)(4), 1391(f), 1441(d), 1602-1611 (2000), and the State Immunities Act, 1978, c. 33 (Eng.), reprinted in 17 I.L.M. 1123 (1978).

5 Elliott Assocs., L.P. v. Banco de la Nacion, No. 96 Civ. 7916 (RWS), 2000 U.S. Dist. LEXIS 14169 (S.D.N.Y. Sept. 29, 2000); Lowenfeld Declaration, supra note 1, I 5.

6 Lowenfeld Declaration, supra note 1, 19.

7 Elliott Assocs., L.P., General Docket No. 2000/QR/92 (Ct. App. of Brussels, 8th Chamber, Sept. 26, 2000).

8 G. Mitu Gulati \& Kenneth N. Klee, Sovereign Piracy, 56 BuS. LAW. 635, 636 (2001).

9 In Belgium, for example, in Republic of Nicaragua v. LNC Investors LLC \& Euroclear Bank S.A., the Commercial Court of Brussels once again issued an injunction, but was reversed in the Cour D'Appel de Bruxelles in March 2004 on the ground that Euroclear was not a proper party to the litigation.

10 Compare Kensington Int'l Lid. v. Republic of Congo, 2002 No. 1088 (Commercial Ct. Apr. 16, 2003) (refusing to enjoin sovereign borrower from making payments of external indebtedness without proportional payment to the plaintiff ), aff'd, 2003 WL 1935493 (C.A. May 13, 2003), with Red Mountain Fin., Inc. v. Democratic Republic of Congo, No. CV 00-0164 R (C.D. Cal. May 29, 2001) (refusing specific performance of pari passu clause but enjoining sovereign borrower from making payments of external indebtedness without proportional payment to the plaintiff).

A pending action in respect of Republic of Congo debt uses a pari passu clause to assert a claim of tortious interference with contract against a later lender who received payments. Kensington Int'l Ltd. v. BNP 
Elliott pulled off its Belgian caper at an inopportune time. The reading of the pari passu clause operative in the Belgian decision strengthens the hands of creditors who withhold consent from sovereign debt compositions. The greater the potential rewards to dissenters, the harder compositions are to conclude. The more unstable the composition process, the longer the duration and greater the intensity of sovereign distress. And in late 2000 , at the time of the Belgian action, there loomed a sovereign debt crisis with a magnitude equaling emerging market (and particularly Latin American) defaults of the 1930s and 1980s. During the 1990s, emerging market borrowers had turned to the bond markets to borrow hundreds of billions in dollars and other currencies." By 2000 , market demand had fallen dramatically as fear of distress intensified. ${ }^{12}$ Argentina was on the brink of default, which followed in 2001. In 2004, Argentina's debt restructuring process remains at an early stage. ${ }^{13}$

Actors in the world of sovereign debt take a dim view of the Belgian injunction. They dismiss it as the maneuvering of a rogue creditor ${ }^{14}$ before a rogue court. ${ }^{15}$ It was, they charge, less action at law than piracy. ${ }^{16}$ The Belgian court, moreover, got it wrong: Sovereign debt contracts do not contemplate these enforcement actions. Compositions make the majority of cooperative bondholders better off because they help to cure distress. Accordingly, bondholders would be "crazy" to assent to debt contracts that held out

Paribas S.A., No. 03602569 (N.Y. Sup. Ct. Aug. 13, 2003). But cf. Nacional Financiera, S.N.C. v. Chase Manhattan Bank, 2003 WL 1878415 (S.D.N.Y. Apr. 14, 2003) (holding that pari passu clause covering Mexican corporate borrower might support an injunction against its paying third party creditors but did not support an intercreditor action).

11 Between 1992 and 1997, credit flowed copiously into emerging markets, averaging $\$ 154$ billion each year. William W. Bratton \& G. Mitu Gulati, Sovereign Debt Reform and the Best Interest of Creditors, 57 VAND. L. REV. (forthcoming 2004).

12 This happened after financial crises in East Asia and Russia in 1997 and 1998. Lenders may have underestimated the likelihood of liquidity crises and other economic distress. Altematively, they may have assumed that troubled sovereigns would be bailed out by the IMF. See generally Daniel K. Tarullo, Rules, Discretion, and Authority in Intemational Financial Reform, 4 J. INT'L ECON. L. 613 (2001).

13 Argentina has offered what it says is twenty-five cents on the dollar and what its creditors say is ten cents on the dollar (discounted to present value). The creditors, who face a coordination problem of unprecedented dimensions, are slowly getting themselves organized. An umbrella Global Committee of Argentine Bondholders was established on January 12, 2004. It represents about half of the private sector debt. Mary Anastasia O'Grady, Americas: Argentina Plays 'Chicken' With the IMF, WALL ST. J., Jan. 30, 2004 , at A13.

14 See Patrick Bolton \& David A. Skeel, Jr., Inside the Black Box: How Should a Sovereign Bankruptcy Framework Be Structured?, 53 EMORY L.J. 763, 782 (2004).

15 Anna Gelpem, Building a Better Seating Chart for Sovereign Restructurings, 53 EMORY L.J. 1119 , 1127 (2004) (noting that the lenders' organization has gone on record saying that rogue courts are a bigger danger than rogue creditors).

16 Gulati \& Klee, supra note 8, at 639. 
encouragements to opportunistic holdouts like Elliott." Meanwhile, pari passu clauses admit of a plausible narrow interpretation that does not extend the right of payment asserted by the vultures. ${ }^{18}$

The contract interpretation issue soon may be joined in the Southern District of New York, where a class of Argentine bondholders has been certified in an enforcement action. ${ }^{19}$ Argentina, fearing aggressive use of pari passu clauses by these plaintiffs, already has moved (without success) for an order precluding the plaintiffs from interfering with Argentina's payments to other creditors. The U.S. government has filed a Statement of Interest in support of Argentina's motion. ${ }^{20}$

The government intervenes in aid of its policy position respecting the sovereign debt crisis. Many actors in the world of international finance, including the International Monetary Fund (IMF), would like to see a sovereign bankruptcy regime instituted for the purpose of ameliorating frictions retarding restructuring negotiations. ${ }^{21}$ The U.S. Treasury opposes the bankruptcy initiative, even as it agrees that the frictions need amelioration. In the Treasury's view, the frictions stem from the terms of sovereign bond contracts and so should be eliminated by rewriting the contracts rather than by imposing an international law mandate. ${ }^{22}$ The Treasury's preference for the narrow reading of the pari passu clause follows from the position that a broad reading would add to the frictions.

There is a gap in this discussion. No one interrogates the possibility that the broad reading of the pari passu clause invoked in Belgium holds out benefits for sovereign bondholders as a group (and not just for a handful of vulture investors). This Article addresses the gap, situating the clause in the economic context of sovereign debt relationships. The Article shows that bond contracts benefit bondholders in three ways when they create frictions that

17 Id.

18 See infra text accompanying notes 35-42.

19 H.W. Urban GMBH v. Republic of Argentina, 2003 U.S. Dist. LEXIS 23363 (S.D.N.Y. Dec. 30, 2003).

20 Statement of Interest of the United States, Macrotecnic Int'l Corp. v. Republic of Argentina, 2004 U.S. Dist. LEXIS 2130 (S.D.N.Y. Feb. 13, 2004).

21 Anne Krueger, New Approaches to Sovereign Debt Restructuring: An Update on Our Thinking, Speech at the Sovereign Debt Workouts: Hopes and Hazards Conference (Apr. 1, 2002), available at http:// www.imf.org/extemal/np/speeches/2002/040102.htm.

22 Under Secretary of Treasury John B. Taylor, Sovereign Debt Restructuring: A U.S. Perspective, Speech at the Sovereign Debt Workouts: Hopes and Hazards Conference (Apr. 2, 2002), available at http:// www.iie.com/publications/papers/taylor0402.htm. 
retard sovereign debt compositions. First, the contracts diminish the likelihood of default by opportunistic sovereigns seeking to externalize the effects of economic reverses. Second, assuming severe financial distress, they make it less likely that the defaulting sovereign will attempt to impose the burden of restructuring on the particular class of bonds. Third, assuming a restructuring, they improve the bondholders' bargaining position. More generally, the pari passu clause, read broadly, constrains the distressed sovereign's range of choices, enhancing the enforcement power of the bonds and arguably lowering the long-run cost of sovereign debt capital.

This explanation justifies judicial attachment of the broad reading without, at the same time, dictating its attachment or rendering the narrow reading implausible or illegitimate. Accordingly, the explanation does not by virtue of its own existence determine the issue of contract interpretation. It instead highlights the difficulty of the case. No trade usage will emerge here to ease the burden on the interpreting court, for actors in the sovereign debt market dispute the clause's meaning in good faith. The court accordingly will bear normative responsibility for the outcome. By way of providing contextual guidance, this Article illuminates the source of the problem, depicting sovereign debt as a world of trade offs and contradictions, where a contract that makes the bondholders better off means one thing on the day it is executed and delivered, and another thing in the event of severe distress later on. With private debt, such contradictions are surmounted through the deus ex machina of a bankruptcy regime. With sovereign debt there is no bankruptcy, forcing the parties to paper over the tensions between ex ante and ex post by drafting vaguely. Intractable questions of interpretation arise in consequence.

Part I describes the disruptive role the pari passu clause plays in sovereign debt compositions, stating the case favoring the narrow reading. Part II reconsiders the economic incentives in play at the time lenders close loans to sovereigns, stating a case for the broad reading. Part III works the competing readings through the legal framework of bond contract interpretation. The exercise shows that the matter comes down to a choice between an ex ante reading, conducted as of the time the contract is executed and delivered, and an ex post reading, conducted as of the later time of distress. The Article concludes that the ex post reading legitimately may be attached to the clause, not because it is correct at all times and in all contexts, but because this is in fact a time of distress. 
I. UnANimous Action, Collective Action, Holding OUT, PRiORity, AND PAYMENT

This Part describes coordination problems and holdout incentives that retard the process of sovereign debt restructuring. Because the broad reading of the pari passu clause aggravates these problems, to describe the restructuring process is to state a policy justification for a narrow reading. A practice-based case for a narrow reading supplements the policy argument.

\section{A. The Policy Case for a Narrow Interpretation}

With private debt, defaults lead to enforcement against debtor property. Left unchecked, a sequence of uncoordinated judgments, levies, executions, and property sales literally tears apart a distressed producing entity. Corporate bankruptcy reorganization prevents this, staying creditor enforcement actions and providing a safe space for a composition bargain that scales down the creditors' payment rights and returns the debtor to fiscal health.

Sovereign debt works differently. Sovereign immunity limits opportunities for direct enforcement. Default accordingly leads to informal, often lengthy standstills instead of destructive "grab races." The creditors wait out the period of distress, expecting eventual economic recovery to lead to a resumption of payments. Payment resumption often requires that the creditors come to the negotiating table to rewrite the defaulted debt contracts. Such a "composition," or "restructuring," scales down the sovereign's obligations. In theory, this causes the sovereign to recover from financial distress more quickly and should make both the sovereign and its creditors better off.

Process barriers must be overcome in the conclusion of a composition. Some stem from information asymmetries, others from coordination problems due to large numbers of creditors. Still others stem from the bond contracts themselves. Boilerplate clauses, called "unanimous action clauses" (UACs), can condition amendment of the bond contract's key payment terms on unanimous bondholder consent. Historically, UACs govern sovereign bonds issued in New York. Sovereign bond contracts executed and delivered in London, in contrast, contain "collective action clauses" (CACs), which permit across-the-board amendments with a three-quarters majority. Where as CACs facilitate restructuring of the defaulting sovereign's debt, UACs stand in the 
way. Corporate debt also tends to contain UACs, but bankruptcy regimes trump the clauses with mandatory collective action. ${ }^{23}$

The feasibility of unanimous creditor consent to a composition depends on the numbers and the lending context. Historically, groups of bank creditors, even large ones, have proved amenable to, if not eager for, such consent. The numbers are small and norms of cooperation are brought to bear against the unruly. ${ }^{24}$ With thickly-traded, bonded debt and thousands of bondholders dispersed around the globe, unanimous action is impossible. At least one bondholder always will say no. An incentive to hold out arises from the very fact that the composition makes the bondholders better off as a group. The opportunistic bondholder withholds its essential vote in hopes of procuring a side payment from the transaction's proponents.

UACs do not present an absolute bar to the restructuring of widely dispersed debt, however. A composition can be effected by indirection. Instead of being asked to vote to amend their bond contracts, the bondholders are asked to exchange their bonds for substitute bonds that contain modified terms more favorable to the debtor. The proponent neither expects nor requests universal participation. Even so, the closing of the exchange offer will be conditioned on supermajority acceptance. Holdouts remain a problem because a freeriding strategy remains available to a bondholder opportunist. Even if no side payment will be forthcoming, saying no to an exchange offer means holding on to the original, unamended bond. Such a hold out retains the benefit of the debtor's original promise to pay and all other contract rights, even as the exchanging majority makes concessions in respect of the timing and amount of payments. If only a few creditors hold out, the exchange offer still succeeds. But if enough creditors succumb to temptation and join the holdouts, the exchange offer fails. More particularly, if the subsidy to the holdouts is greater than the increase in value to the exchanging creditors, every one is better off refusing to exchange. ${ }^{25}$ The failure of the offer makes everybody worse off.

Bond issuers wield a weapon against holdouts in the form of an "exit consent" attached to the exchange offer. Under the New York drafting practice, the contract's payment terms are subject to UACs, while ancillary

23 Bratton \& Gulati, supra note 11.

24 Lee C. Buchheit \& Ralph Reisner, The Effect of the Sovereign Debt Restructuring Process on InterCreditor Relationships, 1988 U. ILL. L. REV. 493, 507-10.

25 Mark J. Roe, The Voting Prohibition in Bond Workouts, 97 YALE L.J. 232, 236 (1987). 
protective promises and process terms are subject to CACs. An exit consent is a proposal to remove these protective provisions by a majority vote amendment under the CAC made simultaneously with an exchange offer. The cooperative, exchanging bondholders approve the amendment even as they exit. This leaves the holdouts with their original principal and interest terms intact but subject to manipulative action by the debtor. For example, a sovereign bond's negative pledge clause, which protects against the creation of security interests in other issues of debt, can be removed by means of exit consents. As drafted historically, sovereign debt contracts also leave their pari passu clauses vulnerable to removal by exit consent. ${ }^{26}$ As protective provisions disappear, the likelihood that the holdouts ever receive their unamended principal and interest payments diminishes. ${ }^{27}$

Indeed, starvation by continued nonpayment is the sovereign debtor's tactic of last resort against holdouts-at least as long as the pari passu clause is read narrowly. Sovereign compositions work very differently from their corporate counterparts at this point in the scenario. Corporate restructuring outside of bankruptcy occurs on a preemptive basis, prior to default. The holdout takes a free ride if the exchange offer succeeds: It is "buoyed up," retaining a bond paying one hundred cents on the dollar even as it joins the creditors who exchanged for scaled-down payments in benefiting from the avoidance of bankruptcy and the debtor's rehabilitation. If the corporate debtor wishes to stay out of bankruptcy after the composition closes, it will have to stay current on payments to the holdout as well as to all other creditors. In the sovereign context the stakes ratchet up on both sides. Many sovereign restructurings occur after a payment default. Because composition means the exchange of old paper for new, it does not cure the default on the old paper. As with Elliott and its Peruvian debt, the holdout retains the power to both accelerate its own debt and claim the entire principal amount to be due presently. The holdout

26 The standard UAC language broadly covers the bondholders' right to payment, and accordingly could be read to cover the pari passu clause. See, e.g., Prospectus Supplement to Prospectus, Government of Jamaica, $10.625 \%$ Notes Due 2017, at 62-63 (June 4, 2002). Here the contract contains a UAC including amendments that would "reduce any amounts payable" or change the "obligation to pay any additional amounts." Arguably, phrases like these refer to money due and owing under the note, rights that would not be affected by lifting of the pari passu clause. But the matter is not free from doubt. Drafters of exchange offers avoid the issue by having the exit consent modify the bond contract's sovereign immunity waiver so as to exclude attachment of amounts paid under the composition. See Prospectus Supplement to Prospectus, Republica Oriental del Uruguay, Offer to Exchange, at S-4 (Apr. 10, 2003) [hereinafter Uruguay Exchange Offer], available at http:/www. bcu.gub.uy/autoriza/sgoioi/reperfilamiento/prospectosup.pdf.

27 On the use of exit consents to engineer a sovereign restructuring, see Lee C. Buchheit \& G. Mitu Gulati, Exit Consents in Sovereign Bond Exchanges, 48 UCLA L. REV. 59 (2000). 
thus is buoyed up much higher with respect to the restructured debt than is the holdout in the corporate case. ${ }^{28}$ But the sovereign debtor has an option unavailable to the corporate debtor: It can get away with leaving the holdout to starve as long as two conditions obtain. First, the holdout must have no viable route to enforcement of its claims, a route held out by the broad reading of the pari passu clause attached in Belgium. Second, the existence of unpaid holdout debt must not destabilize the rehabilitated sovereign's relations with the credit markets. ${ }^{29}$

If pari passu clauses support actions by holders of defaulted sovereign bonds to block payments to other sovereign creditors, then sovereign holdouts occupy much the same bargaining position as their corporate counterparts. ${ }^{30}$ If pari passu clauses do not prohibit payments to favored creditors by sovereigns in default, the potential holdout's calculations are materially altered. As long as the value on offer in the composition is greater than the market value of the bond, even a vulture fund might find participation advantageous. Such a vulture, much like Elliott with its Peruvian bank debt, will have purchased its bonds at a deep discount in the secondary market after the onset of distress and

28 The standard corporate trust indenture inhibits the holdout in an additional respect. Individual holders may bring unilateral enforcement actions only in respect of missed payments of principal and interest; they may not unilaterally accelerate their own bonds. See REVISED MODEL SIMPLIFIED INDENTURE $\$ \S 6.02,6.07$ (2000), reprinted in 55 Bus. LAW. 1115 (2000). For the suggestion that sovereign bonds should be redrafted to follow the corporate pattern and remove the unilateral acceleration right, see Jill E. Fisch \& Caroline M. Gentile, Vultures or Vanguards?: The Role of Litigation in Sovereign Debt Restructuring, 53 EMORY L.J. 1047, 1076-77 (2004).

29 This point follows from the reputation theory of sovereign debt. See infra text accompanying note 44. It does not follow that restructuring contracts can forbid the sovereign from making payments to holdouts. Such a term might open the benefited holders to an action for inducement of breach of contract. See Keith Clark, Sovereign Debt Restructurings: Parity of Treatment Between Equivalent Creditors in Relation to Comparable Debts, 20 INT'L LAW. 857, 863 (1986); $c f$. First Wyo. Bank, Casper v. Mudge, 748 F.2d 713 (10th Cir. 1988) (holding a bank knowingly taking security in violation of a negative pledge liable for tortious interference). Due to this fear of tort liability, contracts in bank restructurings only go so far as to provide that if the debtor pays nonparticipating debt ahead of schedule, it will pay the rescheduled debt pro rata. See Philip R. Wood, Pari Passu Clauses-What Do They Mean?, 18 BuTterworths J. INT'L Banking \& Fin. L. 371, 373 (2003).

Note that the pari passu clause, under the broad reading, induces no defaults; it instead prevents selective compliance with other obligations assuming default on the debt the clause covers. A clause drafted in the negative-in which the borrower covenanted not to make any payments to other creditors-would be more problematic. See Clark, supra, at 863.

30 This is assuming, of course, that the holdout can find no other assets of the sovereign against which to levy execution. 
will be looking for spectacular short-term returns. ${ }^{31}$ Without an easy route to payment in full, the composition itself becomes the source of the quick profit.

The outcome of the interpretation of the pari passu clause has parallel implications for the debate over a sovereign bankruptcy regime. The IMF's proposed bankruptcy architecture would trump UACs and facilitate restructuring in a majority action framework. The U.S. Treasury agrees on the need for majority action even as it rejects bankruptcy, due to a preference for market solutions over regulatory intervention. ${ }^{32}$ Because UACs lie at the core of the process problem and UACs are contract terms, the Treasury is encouraging the parties to sovereign bond contracts to rewrite the terms instead of supporting an international mandate overriding the terms. In the Treasury's view, CACs are superior to UACs from an efficiency point of view, with UACs benefiting only opportunists who hold up rational creditors attempting to enhance value. It follows, says the Treasury, ${ }^{33}$ that sovereign bondholders will freely exchange their existing UAC bonds for CAC bonds, ameliorating the coordination problems. All one need do is make a public offer of the new $\mathrm{CAC}$ bonds and let the market price them. The price will at all events exceed that of the UAC bonds, inducing across-the-board exchanges by the tens of billions of face amount. ${ }^{34}$

The Treasury's intervention has not triggered across-the-board exchange offers eliminating UACs from the existing sovereign debt stock, even as notable progress has been made in the inclusion of CACs in new financings in New York. Meanwhile, the Treasury's opposition stalled the IMF's bankruptcy initiative. ${ }^{35}$ The holdout problem remains on the table as a result. A policy signal for the interpreting judge results: Because the broad reading of pari passu magnifies incentives to hold out where the narrow reading diminishes them, the narrow reading should attach. Significantly, the policy considerations that point to the narrow interpretation also motivate both the IMF bankruptcy initiative and the Treasury's visionary exchange offer.

31 John C. Coffee, Jr. \& William A. Klein, Bondholder Coercion: The Problem of Constrained Choice in Debt Tender Offers and Recapitalizations, 58 U. CHI. L. REV. 1207, 1214 (1991).

32 See Barry Eichengreen, Financial Crises and What to Do About Them, ch. 1 (2001) (unpublished manuscript, on file with author); Taylor, supra note 22.

33 See Taylor, supra note 22.

34 Adam Lerrick \& Allan H. Meltzer, Sovereign Default: The Private Sector Can Resolve Bankruptcy Without a Formal Court (Carnegie Mellon, Gaillot Center for Public Policy, Quarterly Int'l Econ. Report, Apr. 2002), available at http://emcreditors.com/pdf/n_JEC\%20SOV\%20Bankruptcy\%20Study.pdf.

35 Bratton \& Gulati, supra note 11. 
Proponents of the broad reading are left looking like greedy speculators, scheming and wheedling beyond the pale of legitimate justificatory policy.

\section{B. The Practice Case for a Narrow Interpretation}

When a borrower is unable to pay all of its debts as they come due, at least one of its creditors (and likely more than one if it has many creditors) will receive less than the borrower's promised performance. The broad reading of the pari passu clause is addressed to this situation, according protection when one or more, but not necessarily all, creditors will be receiving less than is due and owing. Under the broad reading, the borrower in default undertakes to pay its foreign obligations pro rata to the extent it makes payments at all when in default. The pari passu clause, thus read, means pro rata payment to all so that no creditor receives a de facto preference or priority. ${ }^{36}$

The narrow reading, in contrast, is less purposive and more textual. Return now to the pari passu clause in Peru's defaulted guaranty, which stated that "[ $t]$ he obligations of the Guarantor hereunder do rank and will rank at least pari passu in priority of payment with all other External Indebtedness of the Guarantor, and interest thereon." ${ }^{37}$ Note that the clause never quite says "the Guarantor shall pay." Instead it makes a representation and a promise about "priority of payment." Much hangs on the distinction. The narrow reading's proponents assert that the clause intelligibly can be read to cover "priorities"-rights to payment as against other creditors in contract and in law-as opposed to the payments themselves.

The case for the narrow reading follows from history. The proponents start their historical story a century and a half ago and lay out a succession of narrow functions served by the clause in different transactional contexts. No additional content, they assert, should be added.

The story has four phases. It starts with Victorian railroad bonds. The default rule under British law in those days created priorities in collateral under a common mortgage in accordance with the time of debt issue or the time of debt maturity. ${ }^{38}$ This first-in-time regime did not suit the purposes of bond issuers and holders under open-ended mortgages, who wanted all holders of all

36 Wood, supra note 29 , at 372.

37 Lowenfeld Declaration, supra note 1, 119.

38 Lee C. Buchheit \& Jeremiah S. Pam, The Pari Passu Clause in Sovereign Debt Instruments, 53 EMORY L.J. 869, 895 (2004). 
bonds benefited by the lien to have equal rights. Accordingly, the mortgages provided that a foreclosing creditor acted for the benefit of all holders at the same priority, pari passu. ${ }^{39}$

In the story's second phase, the pari passu clause shows up in sovereign bonds in the early twentieth century. Sovereign borrowers in those days often "earmarked" certain assets or cash flows, attaching the payment streams to stated debt issues without formally conceding liens. These quasi-security interests implied de facto priorities in the subject assets. The practical value of the de facto commitments was questionable, of course. Even so, other lenders objected to the practice. Pari passu clauses appeared in unsecured sovereign debt contracts to forbid earmarking, performing the same function served by negative pledge clauses in issues today.

In the story's third phase, we move forward in time to cross-border bank lending to corporations in the post-war era. Pari passu clauses are included in these contracts to ameliorate legal risks held out by national insolvency regimes. In cross-border lending, nothing guarantees that the borrower's national bankruptcy law operates, like that of the United States and the United Kingdom, to condition a claim's subordination on the claimant's consent. ${ }^{41}$ The pari passu clause is thought to trump unconsented subordination by operation of national law. ${ }^{42}$

Now to the final phase of the story, in which the pari passu clause appears in contemporary sovereign bank loan and bond documentation, once again in

39 Id. at $895-96$

40 Id. at 896-97, 912-13; see also 2 PHILIP WOOD, LAw AND PRACTICE OF INTERNATIONAL FinANCE $\S 6.03[3]$ (1980); William Tudor John, Sovereign Risk and Immunity Under English Law and Practice, in 1 INTERNATIONAL FinaNCIAL LAw 71, 95-96 (Robert S. Rendell ed., 2d ed. 1983).

41 It follows on this reading that U.S. domestic corporate debt requires no pari passu clause because the system does not allow for involuntary subordination. Buchheit \& Pam, supra note 38, at 873-74. This is right so far as it goes. To go a step farther, shift to the broad reading and ask why domestic corporate bonds do not require pari passu payments. The answer is that prior to default, payments are assumed to be unequal because different debt issues have different payment schedules. After default, one of two things happens. If the debtor goes into bankruptcy, the bankruptcy system loosely imposes equality and recaptures a limited class of preferential payments. See II U.S.C. $\$ 1129(b)(1)$ (2000) (containing a prohibition of discrimination in bankruptcy reorganization plans). If the debtor does not go into bankruptcy proceedings, a regime of creditor diligence prevails, and the creditors race to the courthouse under a regime of first-in-time priority. Because the bankruptcy alternative can be resorted to by a creditor concerned that the enforcement actions of others will lead to an unequal result, see id. $\$ 303$ (providing for involuntary bankruptcy petitions filed by creditors), no contractual pari passu provision is necessary. The system does tolerate preferential payments by debtors in distress prior to bankruptcy, subject to Bankruptcy Code $\$ 547$. See id. $\$ 547$; Debra J. Schnebel, Intercreditor and Subordination Agreements-A Practical Guide, 118 BANKING L.J. 48, 49 (2001).

42 Buchheit \& Pam, supra note 38, at 872; see also Buchheit \& Reisner, supra note 24, at 497. 
order to block involuntary subordination. The need for the block intensifies, given a sovereign borrower. Hypothesize a national government wishing to repudiate a predecessor government's debt obligations. It orchestrates a legislative intervention under which the inconvenient debt is subordinated by law to all of its other obligations. The government then claims that positive law prevents payment, tying its hands. The pari passu clause supposedly assures that a positive law payment restraint, whatever its etiology, is not a defense to an action on the contract. ${ }^{43}$ For a more mundane example of a subordination risk under national law, consider a procedure held out by the laws of Spain, the Philippines, and other Spanish-speaking countries. A creditor and a debtor can join together formally to register their debt contract, paying a fee. The reward is a juridical priority over other unsecured creditors. In the pari passu clause, the sovereign debtor promises not to participate in this ritual. It also warrants against the presence of a legal priority ladder applying to unsecured debt. ${ }^{44}$

This four-part story neatly explains the narrow reading of pari passu. We see, say the proponents, why the clause is so opaque: The vague drafting follows from the fact that over time the clause has come to cover multiple problems. ${ }^{45}$

\section{Summary}

The historical story leaves open some questions: Even if all of the foregoing is true, what prevents the opaquely drafted clause from covering preferential payments as well? Does the narrow reading of necessity limit the clause's reach to the concerns identified-priority in law and the lapsed practice of earmarking of revenues-so as to require exclusion of preferential payments? Nothing in the historical account implies such a limit. The limit comes from the contemporary policy context in which the broad reading strengthens the hands of holdouts and discourages compositions.

The narrow reading thus commends itself not because of the history but because the sovereign debt markets have stumbled into crisis. Given the crisis, if all other things are equal, the narrow reading should be preferred because it

43 The ploy is not a defense to enforcement actions in the United States. See Libra Bank Ltd. v. Banco Nacional de Costa Rica, S.A., 570 F. Supp. 870 (S.D.N.Y. 1983); Allied Bank Int'l v. Banco Credito Agricola de Cartago, 566 F. Supp. 1440 (S.D.N.Y. 1983), rev'd 757 F.2d 516 (2d Cir.), cert. dismissed, 473 U.S. 934 (1985). For further discussion, see Buchheit \& Pam, supra note 38, at 913-14.

44 Buchheit \& Pam, supra note 38, at 903-05; Wood, supra note 29, at 371-72.

45 Buchheit \& Pam, supra note 38, at 912. 
makes restructuring easier to accomplish by making holding out less attractive. The question is whether all other things are in fact equal. Part II shows that they are not. It states a case for "priority of payment" to cover payments as well as contractual or positive law priorities even in the context of sovereign distress. The choice between the two readings entails a tradeoff between two rational but inconsistent approaches to the problem presented by distress.

\section{Pari PASSU AND Sovereign Choices: Default AND Priority}

Distressed debtors tend to be conceived as actors without choices. In this picture, defaults occur because resources are exhausted, not because the debtors act strategically; if resources are exhausted no creditor gets paid. The reality is more complicated. Sometimes debtors have a choice as to whether to default. Once in default, debtors may have resources available to pay some but not all of their creditors, making it possible to choose favorites. The pari passu clause, under the broad reading, addresses these choices toward the end of reducing the sovereign borrower's zone of discretion. By making compositions harder to conclude, the clause makes default a less attractive choice and hence less likely to occur. By making preferential payments vulnerable to challenge, the clause makes it less likely that the bonds it protects will bear a disproportionate share of the costs of distress.

Section A discusses the pari passu clause's bearing on debtor incentives to default, applying microeconomic explanations of sovereign debt. Section B discusses the clause's bearing on the defaulting sovereign's choices concerning restructuring and priority.

\section{A. The Choice to Default}

The economics of sovereign debt build on the following axiom: Unless default imposes some cost on the debtor, not only will the debtor not pay the debt, the lender will not make the loan in the first place. ${ }^{46}$ Sovereign lending presupposes that default has a cost. The lower that cost, the smaller the sovereign's borrowing capacity; the greater the cost, the more willing the lenders are.

46 Gabrielle Lipworth \& Jens Nystedt, Crisis Resolution and Private Sector Adaptation, 47 IMF STAFF PAPERS 188, 192, 195 (2001), available at http://www.imf.org/External/pubs/FT/staffp/2000/00-00/ln.pdf. 
The threshold problem for the economics of sovereign debt is to identify the cost that satisfies the axiom. The problem admits of no easy solution because sovereign creditors lack conventional means of enforcement by levy and execution against debtor property. The exercise of working through the debate isolates aspects of sovereign debt relationships that make credible the broad reading of the pari passu clause.

\section{Reputation in the Credit Markets}

Under one school of thought, the cost of sovereign default lies in exclusion from future borrowing. The leading model assumes that national economies are cyclical and that people prefer to consume evenly across the cycles. Given this, it makes sense for the state to borrow on the downward cycle to fund consumption and later to repay the loans with returns generated on the upward cycle. The defaulting sovereign converts to itself a gain from trade-the extemporal consumption trade across the business cycle. In the model, the default triggers a lender embargo. The debtor ends the embargo by transferring the converted surplus to the lenders, its rightful owners. ${ }^{47}$ The cost of default to the sovereign is the cost of being shut out of the credit markets on the upward cycle and associated consumption constraints on the next downward cycle. ${ }^{48}$ Access to the credit markets being the key, this is termed the "reputational" model of sovereign debt.

On first inspection, this description supports the narrow reading of the pari passu clause. If a high-powered interest in credit market access determines the sovereign's behavior, then the sovereign will only default in the event of an unanticipated shortage of resources due to an external shock or other

47 As long as the transfer is made, the credit moratorium can be a short one. See Kenneth M. Kletzer \& Brian D. Wright, Sovereign Debt as Intertemporal Barter, 90 AM. ECON. REv. 621 (2000). The credit inflows to Latin America in the early 1990s in the wake of Brady restructurings provide a good example of this. See Charles W. Calomiris, How to Resolve the Argentine Sovereign Debt Crisis (AEI Papers \& Studies, Apr. 16. 2001), available at http://www.aei.org/include/pub_print.asp?pubID=14869.

48 In this picture, the only state that repudiates its debt is the state that never plans to borrow again. Lipworth \& Nystedt, supra note 47, at 189-90. More elaborate articulations of this reputational model open up the class of defaults to distinguish between strategic and distress situations and expand the lenders' behavior pattern to allow for the possibility of forgiveness. See Harold L. Cole et al., Default, Settlement, and Signalling: Lending Resumption in a Reputational Model of Sovereign Debt, 36 INT'L ECON. REV. 365 (1995) (developing a model of how defaulting sovereigns lose access to credit markets and work to regain access); see also Michael R. Tomz, Sovereign Debt and International Cooperation: Reputational Reasons for Lending and Repayment (Oct. 2001) (unpublished manuscript, on file with author) (describing how sovereign lenders who default can re-enter the lending markets by incurring the high-cost signal of repaying their earlier debts and showing themselves no longer to be "lemons"). 
misfortune. The liquidity crises suffered by several emerging market debtors in the 1990s provide a good example of such severe distress: Nonresidents suddenly pull out their capital and resident capital responds by fleeing to other jurisdictions; liquidity quickly disappears and the economy is literally unable to meet external obligations. ${ }^{49}$ Sovereigns defaulting in such situations have no choice in the matter. It follows that contract terms play no role in discouraging these defaults. At the same time, once the liquidity crisis eases, the defaulting sovereign has every incentive to present a plan of composition that returns it to the good graces of the credit markets. This is the point in the description when contract terms become pertinent: If a term creates a friction that retards the negotiation process, it arguably fails cost-benefit inspection. Doubts arise with respect to both UACs and the broad reading of the pari passu clause.

The picture changes if we modify the assumption concerning the intensity of the sovereign's desire to maintain its reputation in the credit markets. In this modified picture, the sovereign remains concerned about its reputation but can be influenced by competing concerns. Hypothesize that the sovereign's economy lapses into distress slowly. At some point the question arises as to whether the economy can sustain the debt load out of its own resources. A good faith decision as to medium- or long-term unsustainability can be made, even though the sovereign's foreign exchange reserves remain sufficient to meet near-term payments. ${ }^{s 0}$ In this scenario, default comes to make sense as an act of political will: Actors in the national government (along with their domestic political opponents) decide that the tax burden and administrative costs of continued debt service are intolerable and that the burden of payment (political as well as economic) outweighs the costs of default. ${ }^{51}$

If we relax the intensity of the sovereign's desire to maintain its reputation one step more, a strategic default becomes possible. ${ }^{52}$ This is an opportunistic breach stemming from the debtor's desire to siphon off the payment flow on the loan for another purpose. Because debt payments reduce current income,

49 Punan Chuham \& Federico Sturzenegger, Default Episodes in the 1990s: What Have We Learned? 5 (July 25, 2003) (unpublished manuscript), available at http://www.utdt.edu/departamentos/empresarial/cif/ pdfs-wp/wpcif-112003.pdf.

50 Id.

51 Jonathan Eaton, Debt Relief and the International Enforcement of Loan Contracts, J. ECON. PERSP., Winter 1990, at 43,48-49. For example, only one of the nations in default in the Latin American debt crisis of the 1980 s, Chile, owed as much as one year's gross national product. See Jeremy Bulow \& Kenneth Rogoff, $A$ Constant Recontracting Model of Sovereign Debt, 97 J. POL. ECON. 155, 156 (1989).

52 Lipworth \& Nystedt, supra note 47, at 195. 
default is welfare-improving as long as consequences in the credit markets carry little weight in the cost-benefit analysis.

In both of these scenarios-a good-faith distress default resulting from political and economic calculation and a strategic default-the sovereign makes choices. It follows that the debt contracts can play a role in influencing the sovereign's choices, at least as long as the sovereign retains an interest in a future return to the credit markets. Pari passu clauses (under the broad reading), along with UACs, make the composition process more costly, adding to the costs of default. In so doing, they delay distress defaults and discourage strategic defaults. ${ }^{53}$ Because they make default less likely, they benefit the sovereign by increasing its debt capacity. In addition, the sovereign that commits to high restructuring costs at the negotiating table signals its status as a good credit, lowering the cost of borrowing. ${ }^{54}$

An efficiency question arises at this point in the analysis. Costs of default could be too high (greater debtor welfare loss than needed for the given measure of creditor protection) or too low (default cost insufficient to import an incentive to perform). Professors Bolton and Skeel here intervene to argue that sovereigns have perverse incentives to commit to excessively costly defaults. Information asymmetry supplies one explanation for this-the sovereign that commits to high restructuring costs signals its confidence in its ability to pay. Another reason is political-a given government may borrow heavily to satisfy short term objectives. Contract forms that make default expensive expand the government's borrowing capacity and so suit the purposes of these short-sighted political actors. The actors, however, underweigh the long-run costs of the contract terms because the costs are incurred after their terms of office.

The pari passu clause may or may not be economically efficient under the broad reading. Bolton and Skeel's analysis suggests that it is not. ${ }^{55}$ But the

53 Contrariwise, if a decrease in the cost of default is welfare maximizing, default is too expensive. Id. at 199.

54 Bolton \& Skeel, supra note 14, at 771. Bolton and Skeel argue that the incentive problem would be corrected by a regime of first-in-time priority. Under this, the sovereign's borrowing room would shrink as the amount of debt increased. The cost of each successive borrowing would rise, discouraging more debt. In the present pari passu regime, in contrast, each borrowing ranks equally, encouraging overborrowing. The cost of capital is higher than it would be under the first-in-time regime because the first lender raises its rate in anticipation of later claim dilution. $I d$. at 788-90.

55 Cf. Patrick Bolton \& David S. Scharfstein, Optimal Debt Structure and the Number of Creditors, 104 J. POL. ECON. 1 (1996). Working with a stylized description of the private borrower, Bolton and Scharfstein hypothesize that a low-quality firm would find it optimal to maximize its liquidation value. A distress default 
analysis simultaneously suggests that the parties to sovereign bond contracts have every reason to subscribe to the broad reading as a purposive matter. An inefficient term may nevertheless be the term intended and the inefficient meaning may be the meaning understood in the market.

\section{The Defecting Lender}

Return now to the reputational model of sovereign debt as originally described above and assume a sovereign with such an overwhelming incentive to maintain its reputation that it will default only involuntarily. In this scenario, contract terms that make default more costly impose a deadweight cost. But a distinction opens up at this point between a UAC and a pari passu clause under the broad reading, with the UAC imposing a deadweight cost and the pari passu clause holding out a benefit to the creditors even as it adds a friction. If the sovereign debtor has a high-powered incentive to regain access to the credit market, then the lender's primary problem lies less with the default itself than with the possibility of opportunistic behavior on the part of other lenders in the wake of default. A lender with no exposure to the defaulted debt could break ranks with the unpaid creditors, ignore their moratorium, and make a new loan to the defaulting sovereign. This new source of credit diminishes the sovereign's incentive to reach a composition with its unpaid lenders. The new lender's very appearance satisfies the sovereign's reputational objective. As long as such a lender is in the picture, even a highly motivated sovereign might find strategic default a viable option.

Kensington International Ltd. $v$. Republic of Congo ${ }^{56}$ provides a real world example of this incentive problem. Congo incurred the debt in question in 1984, but made no payments after 1985. Congo continued to tap credit markets in the industrial world through a wholly owned alter ego called Sociéé Nationale des Petrole du Congo (SNPC). SNPC procured and secured funds for Congo's petroleum operations in blatant violation of the negative pledge clause in the 1984 debt contract. ${ }^{57}$ So low is the stock of loyalty among lending institutions that blue-chip banks in France and Canada happily did

being likely, it would want contracts carrying as little cost as possible in the event of default. The smaller the number of creditors and the lower the voting barrier, the cheaper the liquidation and the greater the value of the debt. Id. at 3. A high quality firm, in contrast, presents little risk of a distress default. Here, Bolton and Scharfstein see strategic default as the dominant problem. Factors increasing the cost of such a default-such as multiple creditors and tougher voting rules-enhance the value of the debt. Id.

562002 No. 1088 (Commercial Ct. Apr. 16, 2003), aff'd, 2003 WL 1935493 (C.A. May 13, 2003). The vulture plaintiff in this case did not manage to procure an injunction.

57 Id. at 15-26. 
business with SNPC, even as its alter ego remained in default on earlier obligations.

In the economic models, the reputational mechanism returns to working order if the original lenders persuade the sovereign borrower to cheat the interloping lender. ${ }^{58}$ With the interloper thrown into the composition process with the other unpaid lenders, the threat of refusal to lend once more becomes a cost to the borrower. In the real world, a pari passu clause, broadly interpreted, could provide the unpaid creditors a more effective assist. The defaulting sovereign can subvert the reputational system only by servicing its new borrowings while simultaneously remaining in default on its old borrowings. The broad reading prohibits this ploy, forcing the sovereign to make pro rata payments to both old and new lenders. For the lenders, the problem less concerns the meaning of the clause than, as usually is the case with sovereign debt, with finding a way to get the clause enforced. Elliott Associates' action in Belgium did just that. ${ }^{59}$

\section{Indirect Enforcement}

A second economic model of sovereign debt is built around the possibility of sanctions. This theory asserts that a sovereign might rationally repudiate its debts even when it needs a future source of finance to smooth consumption in downward cycles. The model depicts a sovereign at the end of an upward cycle. It possesses a cache of capital with which to pay the debt incurred on the previous downward cycle. In the model, the solvent sovereign has a choice. It can either pay the debt or it can default and invest the capital in an insurance contract designed to protect it against the next downturn. When this investment opportunity is available, the rational sovereign defaults because in the long run saving and investment have a higher return than borrowing and repaying. When saving and investment of the purloined capital accompany the default, the sovereign grows faster, increasing its consumption with every turn of the cycle. ${ }^{60}$ It follows that the sovereign's incentive to please the credit markets is unreliable and sovereign debt cannot be sustained on a basis of

\footnotetext{
58 Kletzer \& Wright, supra note 47 , at 622.

59 See supra text accompanying notes 7-9.

60 William B. English, Understanding the Costs of Sovereign Default: American State Debts in the I840's, 86 AM. ECON. REV. 259, 267 (1996). If the debtor has no place in which to invest, the reputational concern causes it to honor the debt. See Harold L. Cole \& Patrick J. Kehoe, The Role of Institutions in Reputation Models of Sovereign Debt, 35 J. MONETARY ECON. 45, 47 (1995).
} 
reputational enforcement. The lender must have some additional recourse with which to inflict a financial cost on the defaulter. ${ }^{61}$

A question arises at this point as to the viability of the lenders' real world enforcement arsenal. Sovereigns in default tend not to leave obvious assets in plain view abroad for creditor attachment. Diplomatic and military assets are exempt. Central bank assets tend to have stronger immunities in the United States and the United Kingdom than other sovereign assets. ${ }^{62}$ State-owned airlines are cited as an exception to the rule, and some Russian creditors managed to bring credible enforcement actions in the late $1990 \mathrm{~s}^{63}$ But as a general matter, the markets do not rely on direct enforcement. The enforcement theory of sovereign debt accordingly emphasizes indirect costs the defaulting sovereign incurs in evading its creditors. Its foreign trade must be conducted in roundabout ways; it loses access to short-term trade credits like bankers' acceptances; and when it places an asset abroad a costly dummy entity must be used. Proponents of the enforcement theory contend that even if the costs of evasion are small in relation to GNP, the costs still will loom large enough in comparison to the defaulted interest to make repudiation inconvenient; if the costs of default do not exceed five percent of total trade, they say, few countries show a net gain on debt repudiation. ${ }^{64}$

The example of Congo raises doubts about the enforcement model. But credibility follows when the direct costs of default to the sovereign's economy are added to the indirect costs of evasion. Default tends to implicate a currency and banking crisis that disrupts the sovereign's domestic financial system and limits the availability of financial resources. Confidence declines, and with it economic performance. In the 1990s, a currency crisis implied a

61 Bulow \& Rogoff, supra note 51, at 157-58; see Jeremy Bulow \& Kenneth Rogoff, Sovereign Debt: Is To Forgive To Forget?, 79 AM. ECON. REV. 43 (1989).

62 As these assets are immune from prejudgment attachment in the United States and United Kingdom, the sovereign has time to shift them to a safe place before a creditor gets a chance to levy execution. Gelpern, supra note 15 , at 1121-22.

63 Bolton \& Skeel, supra note 14 , at 782

64 Bulow \& Rogoff, supra note 51, at 158-59, 167, 174-75. The model's opponents argue that recent debt crises have yielded little evidence of lender interference with the trade of defaulters. Kletzer \& Wright, supra note 47 , at 622 . Moreover, it is not entirely clear why the lenders would want to interfere with the trade of a defaulting debtor, at least given a distress default. Choking the debtor's trade only prolongs the distress and further delays the payment stream. Historians have found evidence to support both theses. Compare English, supra note 55 (arguing that defaults of American states during the 1840s support the reputational model), with James Conklin, The Theory of Sovereign Debt and Spain Under Philip II, 106 J. PoL. EcoN. 483 (1998) (arguing that the history of the sixteenth-century relationship between the Genovese bankers and the Spanish crown supports the enforcement model). 
two percent annual decline in output growth across a five-year period. ${ }^{65}$ These costs of crisis import a credible incentive to repay. ${ }^{66}$

The enforcement model delivers us to the same ambiguous endpoint reached with the reputation model. Coordination problems stemming from UACs and pari passu clauses still raise a concern about postdefault transaction costs. If, as some assert, sovereigns as a practical matter only default under identifiably bad conditions ${ }^{67}$ and strategic defaults are not a practical possibility, it follows that the costs of default are sufficient to import incentives to perform. Indeed, default might cost too much. But others assert that both strategic default and distress default are active possibilities. ${ }^{68}$ If strategic defaults are possible, then the costs of default stemming from loss of confidence, loss of credit, and trade disruption are arguably too low. In this view, transaction costs stemming from UACs and pari passu clauses also are costs of default and so may have a beneficial deterrent effect. Finally, note that what is at bottom a default due to distress may nevertheless entail a political choice among costly courses of action. As long as the sovereign has a choice as to whether to default, strategy inheres in the fact pattern, and added default costs may satisfy the cost-benefit test. ${ }^{69}$

\section{B. De Facto Priorities and the Terms of the Composition}

Now assume that the sovereign has defaulted, whether involuntarily or as a strategic decision. A new range of choices opens up. The sovereign first decides which issues of debt will be restructured and which will not. Having made that decision, the sovereign determines the terms of the composition package. $^{70}$ The pari passu clause, broadly read, can influence the sovereign's decision in the bondholders' favor at both stages.

65 Chuham \& Sturzenegger, supra note 49 , at 3.

66 Id. at 6 . An analogy to indirect bankruptcy costs in the private sector is noted. See Edward I. Altman, A Further Empirical Investigation of the Bankruptcy Cost Question, 39 J. FIN. 1067 (1984) (estimating indirect costs of bankruptcy).

67 Herschel I. Grossman \& John B. Van Huyck, Sovereign Debt as a Contingent Claim: Excusable Default, Repudiation, and Reputation, 78 AM. ECON. REV. 1088, 1088 (1988).

68 See, e.g., Lipworth \& Nystedt, supra note 46, at 193.

69 The foregoing analysis implies a debt ceiling for each sovereign. The greater the borrowed amount, the greater the benefit of default and the more likely default is signaled by the borrower's cost-benefit analysis. The total debt load should not be permitted to approach that level. Jonathan Eaton \& Mark Gersovitz, Debt with Potential Repudiation: Theoretical and Empirical Analysis, 48 REV. ECON. STUD. 289, $289-90$ (1981). The debt ceiling will rise, however, as the creditors' enforcement devices make default more costly for the debtor.

70 Ideally, a distressed sovereign restructures prior to default. When a debtor with a current payment 


\section{Priority as Sovereign Choice}

With corporate debt, priorities follow from explicit contract terms or are imposed by legal regimes. A security interest or mortgage creates a priority for its holder; both are enforced in bankruptcy. In addition, the bankruptcy system accords priority in law to favored creditors, such as taxing authorities, new lenders, and counsel.

Sovereign debt is different. Given barriers to enforcement, contracted-for security interests and subordinations have dubious value. ${ }^{71}$ The priorities that count are created as a matter of practice. A sovereign debtor in distress, although lacking cash to service all of its obligations, very well may have cash to service some of its obligations. Once in default, the debtor chooses which creditors get paid and which do not. Obligations are excluded from restructuring, and thereby effectively prioritized, if the sovereign deems the exclusion convenient to its own financial interests. ${ }^{72}$ If the creditors selected for nonpayment ever want to see any money, they will have to consent to restructuring. The practice of selection implies a powerful case for the broad reading of pari passu.

To see the case, consider first the pattern of de facto priority that prevailed in the sovereign debt crisis of the 1980s. Bank creditors were largest in amount and made up the core group chosen for restructuring. Bondholders, in contrast, tended to be exempted. ${ }^{73}$ Restructuring of dispersed bond issues was widely thought not to be feasible, whether due to the existence of anonymous bearer paper or the presence of uncooperative, litigious holders. ${ }^{74}$ Even if restructuring in fact was feasible-Costa Rica closed a bondholder exchange offer in the late $1980 \mathrm{~s}^{75}$-it was thought not to be cost effective. The

record begins to experience liquidity problems, a composition can be the means to avert default. The objective will be to delay near-term maturities, stretching out the payment schedule and reducing the near-term interest burden. There will be a basis for trade with the creditors if, due to the borrower's distressed condition, the debt is trading at a substantial discount on an expectation that payment in full will not be forthcoming. The composition relieves the near-term payment burden and averts the risk of default. Because default carries collateral costs for the creditors and debtor both, avoidance of default of itself can cause the price of the bonds to increase. Each of Pakistan, Ecuador, and Ukraine successfully closed exchanges along these lines in the late 1990s. In the latter two cases, the price of the bonds went up twenty to thirty percent. Lipworth \& Nystedt, supra note 46, at 208. Argentina and Turkey followed in 2001. See Eichengreen, supra note 32, ch. 3.

71 Bolton \& Skeel, supra note 14, at 766-67 (noting that in 1999 Ecuador included collaterized Bradies in its restructuring, frustrating the market's expectation that the collateral implied a priority).

72 Lee C. Buchheit, Of Creditors, Preferred and Otherwise, INT'L FIN. L. REV., June 1991, at 12.

73 The rule was not absolute. Clark, supra note 29 , at 861 .

74 Buchheit, supra note 72, at 12-13.

75 Clark, supra note 73 , at 861 . 
defaulting debtors of the era tended not to have issued significant amounts of bonded debt, and so found it convenient to exempt their bonds and maintain their reputations in the bond markets. ${ }^{76}$ Secured debt, new credits, debt under foreign exchange contracts, and debt subject to outside foreign guaranties also tended to be exempted, ${ }^{77}$ as of course was debt owing to the IMF and Paris Club members. ${ }^{78}$ The treatment accorded classes of trade creditors and shortterm lenders varied from case to case. ${ }^{79}$ As to the banks, there was no choice but to default.

The practice of bondholder exclusion was exploited in the Brady restructurings. The banks exchanged their illiquid loans for bonds, with the bonds' liquidity and de facto prior status both seen as sweeteners. ${ }^{80}$ The story even circulated that Brady Bonds were "default-risk-free" due to mandatory prepayment clauses, sharing clauses, individual holder acceleration rights, and the like. ${ }^{81}$ This was nonsense, of course. Any corporate bondholder could have disabused actors in the sovereign market of the notion that payment and enforcement clauses assure performance; the sovereign bond market itself falsified the story with its histories of booms and busts. ${ }^{82}$ But financial optimism and the incredible stories it spawns prevailed for some years.

The bond priority story continued to be told as the bond market replaced the banks as the primary source of emerging market debt capital during the 1990s. The story's implausibility became manifest: As bonded debt stock grew in magnitude, its inclusion in restructuring became inevitable, whatever the process frictions. ${ }^{83}$ But, in the eyes of the market, falsification did not occur until 1999, when, in connection with Pakistan's restructuring, the Paris Club determined that the bondholders should be included along with other creditors. ${ }^{84}$ The same thing occurred soon thereafter with Ecuador and Ukraine. All three exchange offers closed successfully, ${ }^{85}$ even as actors in the

76 Lee C. Buchheit, Cross-Border Lending: What's Different This Time?, 16 NW. J. INT'L L. \& BUS. 44, 49 (1995).

77 Clark, supra note 29 , at 862-63.

78 See Gelpern, supra note 15 , at 1127.

79 Clark, supra note 29 , at 863 .

80 See Buchheit, supra note 72 , at 13.

81 Chuham \& Sturzenegger, supra note 49 , at 20.

82 Cf. Buchheit, supra note 76, at 45-46 (describing bond market cyclicality).

83 Id. at $48-50$.

84 Gelpern, supra note 15 , at 1124-25.

85 Lipsworth \& Nystedt, supra note 46, at 206. In the latter two cases, the price of the bonds went up twenty to thirty percent because the markets, worried about holdouts, previously had doubted that the gain due to restructuring could be accessed at all. Such dramatic increases may not occur again. Henceforth, prices of 
bond market warned of higher borrowing costs for emerging markets due to the loss of the assumed priority. ${ }^{86}$ Meanwhile, defaulting sovereigns have continued to make priority choices. Whereas Ecuador and Argentina defaulted across the board, Russia, the Ukraine, and Pakistan limited their defaults to selected instruments. ${ }^{87}$

Consider the implications of the choice between the broad and narrow meanings of pari passu in the bond market prior to Pakistan's 1999 restructuring. The illusion of priority treatment still circulated, even as a manifest risk of inclusion in restructuring grew with the bonded debt stock. UACs made perfect sense in that context because they enhanced the probability of exclusion by adding to the frictions of restructuring. The pari passu clause, broadly read, did the same thing. Under it, a holdout excluded from the payment stream by the sovereign could accelerate its own bond and then use litigation to force its point. The better stocked the holdout's contractual arsenal, the greater the likelihood of exclusion.

Now reconsider the narrow reading in light of the foregoing. It certainly makes sense for the clause to cover the contractual and juridical priorities identified by proponents of the narrow reading. But to restrict the clause's reach to this limited class denudes it of most real world value because the economically pertinent priorities in sovereign debt are de facto. To address them, the clause must cover payment itself as well as priority of payment. In the corporate debt context, in contrast, a bright line distinction between priority and payment might make sense, because legal priorities affect the status of classes of debt under bankruptcy reorganization plans long before any cash crosses the table. ${ }^{88}$ With sovereign debt, where there is no bankruptcy reorganization, a bright-line distinction between priority and payment makes little sense. Here, legally articulated priorities have no effect unless they impact payment; payment and priority are the same thing.

\section{The Terms of the Composition}

Now assume that the pari passu clause has not succeeded in its primary purpose of contributing to a successful case for exclusion from restructuring.

bonds of sovereigns in impending distress will reflect the possibility of successful composition prior to the exhaustion of liquidity. Id.

86 Gelpern, supra note 15 , at 1124-25.

87 Id. at 1141. Ecuador initially excluded its Eurobonds even as it included its collaterialized Bradies. The market did not stand for that. $I d$.

88 See 11 U.S.C. $\$ 1129$ (b) (2000) (distinguishing between secured and unsecured debt). 
The sovereign has defaulted and no money will be paid until an exchange offer has closed successfully. What role, if any, does the pari passu clause play at this stage of the game? Finding an answer means first addressing a preliminary question: Why do unpaid creditors voluntarily agree to take less than they were promised, instead of waiting out the distress and insisting that the renewed debtor make them whole in accordance with its original promises?

For a simple scenario in which the debtor plausibly can negotiate for a reduction in interest rate or principal amount owing, assume an enforcement model of sovereign debt. Assume also that the lenders have a costly punishment available. Deployment of the punishment is cost-effective for the lenders, but the expected yield is less than the principal and interest owed. Given all of this, the borrower can come to the table with an offer of compensation exchanged for the lenders' withholding of the sanction. As long as the borrower offers more than the creditors' expected return from the sanction, they will settle for less than they were originally promised. ${ }^{89}$ Further, the creditors cannot credibly commit in advance to refuse to renegotiate. ${ }^{90}$

Now switch to a reputational model. We still can posit that creditors rationally might make concessions, even if the sovereign remains in distress. The overhang of unpaid loans could discourage new public investment holding out a possibility of high returns. If the forgiveness of some of the debt restores the incentive to invest, it can be in the creditors' interest to make a concession. The new investment benefits the sovereign's economy, making the debt (valued after the concessions) worth more than it would have been worth without the concessions and the new investment. ${ }^{91}$

Generalizing, the sovereign can get the creditors to approve a composition if the new debt it offers will have a market value greater than that of the defaulted debt. Restructuring is feasible if the sovereign can offer a surplus. For both the sovereign and the lenders, the restructuring negotiations address the division of the surplus. The debtor comes to the table with some bargaining power. Money has a time value, and the future state of the debtor's economy remains uncertain even to creditors possessed of full information. Both factors can make a deal holding out a resumption of payments highly

89 Eaton, supra note 51 , at 50-51.

90 Conklin, supra note 51, at 493-94 (explaining Bulow's and Rogoff's model).

91 See Joseph E. Stiglitz \& Andrew Weiss, Credit Rationing in Markets with Imperfect Information, 71 AM. ECON. REV. 393 (1981). This has been described as the "debt Laffer Curve," because forgiving part of the debt dramatically increases the prospects for repayment of the remaining obligation. Kenneth Rogoff, Symposium on New Institutions for Developing Country Debt, J. ECON. PERSP., Winter 1990, at 3, 5. 
attractive. Institutional concerns also can incline creditors toward acceptance. In addition, the debtor may be able to take advantage of collective action problems on the creditors' part, framing a low-ball offer with coercive terms. Exit consents, along with the threat of delisting of the old bonds, further enhance its position.

But the creditors also can wield bargaining power, particularly if they incur the costs of organizing themselves. Waiting has an option value, so the debtor cannot assume that any offer holding out an increase in the price of bonds will garner sufficient support. Sweeteners may have to be added. These take many forms: The interest rate on the restructured debt could be increased to compensate for a repayment deferral ${ }^{93}$ cash payments could be offered; the new bonds could hold out enhanced liquidity; the terms of covenants could be improved; third-party guarantees could be added; or "value recovery rights" could be added, causing payment to be increased along with the performance of a macroeconomic factor. ${ }^{94}$ Upside kickers also have been devised: With exchange warrants, the holders get an option to increase their participation; with extension warrants, holders get an option to exchange for longer-maturity instruments.

With such a restructuring negotiation in view as a possibility, reconsider the choice between a UAC and a CAC. A rational bondholder might well opt for a UAC. The question is whether the debtor will make a higher offer if all the bonds have UACs than if all the bonds have CACs. There is reason to think it will. ${ }^{96}$ Given information asymmetries and different subjective profiles, the creditors will have a range of upset prices respecting acceptance of the debtor's offer. If the debtor needs one hundred percent or a supermajority, it will have to increase its offer to meet the reservation prices at the higher end of the creditors' range. ${ }^{97}$ The UAC thus counteracts the disorganized creditors' tendency to cut and run to take a lowball offer. Of course, a UAC creates a holdout problem even as it causes the offer to rise. But if the offer makes a

92 Chuham \& Sturzenegger, supra note 49, at 25.

93 Id.

94 Id. at $8-9$.

95 Id. at 8.

96 Bolton and Scharfstein suggest that the greater the number of creditors and the higher the percentage of creditor votes needed to approve a renegotiation, the lower the debtor firm's surplus in the renegotiation. Bolton \& Scharfstein, supra note 55 , at 18 .

97 This is the nule of downward-sloping demand. See generally Richard A. Booth, Discounts and Other Mysteries of Corporate Finance, 79 CAL. L. REv. 1055 (1991); Lynn A. Stout, Are Takeover Premiums Really Premiums? Market Price, Fair Value, and Corporate Law, 99 YALE L.J. 1235 (1990). 
generous split of the surplus, holdouts will not be so numerous as to threaten the deal. No one ever expects one hundred percent participation in a composition under UACs, yet such exchange offers close all the time under UACs on the basis of supermajority acceptance. Ecuador recently got ninetyseven percent participation in an offer with an eighty-five percent minimum participation requirement. ${ }^{98}$ Meanwhile, none of those complaining about the holdout problem offers evidence that holdouts regularly cause exchange offers to fail. ${ }^{99}$ When offers do fail, it may be that they are too low and as a result attract something much less than a supermajority of creditors. ${ }^{100}$

The standard negative pledge clause and the pari passu clause, broadly read, also play a role in improving the creditors' hand at the negotiating table. Suppose the sovereign owes $\$ 100$ and claims to have the resources to support a payment of only $\$ 50$. The sovereign plays hardball, making a take-it-or-leaveit exchange offer of a substitute debt contract with a face amount of $\$ 50$. The creditors believe the sovereign can pay $\$ 70$ and refuse to exchange. So the sovereign goes another round, but this time makes the new debt, still with a face amount of $\$ 50$, senior to the debt in default. If the creditors do not have a pari passu clause in their old bonds, they will be forced to accept the offer (at least on an enforcement model of sovereign debt). The reason is that holding out leaves the holder with a claim for $\$ 100$ against an asset base that certainly will be less than $\$ 50$, because the new bonds get paid first. ${ }^{101}$ Alternatively, the sovereign could have the new debt secured by a payment stream at its disposal, at least as long as the old bonds have no negative pledge clauses. The addition of seniority or security in the new issue imports an element of coercion-a powerful incentive for the creditors to cave in and take half a loaf. ${ }^{102}$

98 Chuham \& Sturzenegger, supra note 49 , at 25.

99 Stuart C. Gilson, Transactions Costs and Capital Structure Choice: Evidence from Financially Distressed Firms, 52 J. FIN. 161 (1997) (showing that the holdout problem does not seem to be so severe as to prevent the accomplishment of restructurings respecting private debt, particularly given use of coercive devices like exit consents); see also Jean Helwege, How Long Do Junk Bonds Spend in Default?, 54 J. FIN. 341 (1999).

100 See Marcel Kahan \& Bruce Tuckman, Do Bondholders Lose from Junk Bond Covenant Changes?, 66 J. Bus. 499 (1993) (studying fifty-eight consent solicitations in which an issuer of widely held debt requested modification of existing covenants but did not request either interest deferral or principal forgiveness and showing that in forty-two percent of the cases, the issuers sweetened the terms after an initial failure to obtain consents).

101 Guillermo A. Calvo, Globalization Hazard and Delayed Reform in Emerging Markets, LACEA Presidential Address 13 (Oct. 18, 2001), available at http://www.depeco.econo.unlp.edu.ar/jemi/2002/ trabajo2.pdf.

102 The classic corporate case involving such an offer is Barrett v. Denver Tramway Corp., 53 F. Supp. 198 (D. Del. 1943), aff'd 146 F.2d 701 (3d Cir. 1944). 
Because the bonds on offer in the preceding example benefited from a formal priority, the creditors needed only the narrow reading of pari passu to upset the coercive exchange offer (provided that, like Elliott in Belgium, they found funds to attach or block). With a change of facts, they will need the broad reading. In this version, in the second round, the sovereign makes the same offer of $\$ 50$. No priority is added to the new debt. The sovereign instead drafts the new debt so that continuing default on the old debt triggers no default on the new debt and announces its intention to make no payments on the old debt until the new debt is paid in full. The sovereign also announces that it will delist the old debt from the bond trading exchange, which threatens the holders with illiquidity. Does a rational bondholder tender or not? The new debt's priority now is de facto, but just as real. ${ }^{103}$

The question whether to take the stingy $\$ 50$ offer ultimately goes to the credibility of the sovereign's threat not to pay the old debt. The threat has credibility to the extent, first, the sovereign can gain renewed access to the credit markets if the stingy exchange offer succeeds, and, second, the sovereign finds continuing evasion of creditor enforcement actions by the old bondholders cost beneficial. By tendering, the bondholder gets a bond worth $\$ 50$. If the bondholder refuses to tender but the offer succeeds, the old debt loses its liquidity, and despite its face value of $\$ 100$, may be worth less than $\$ 50$. If the bondholders organize and resist, they may be able to defeat the offer and force the sovereign to pay more than $\$ 50$. If they are disorganized, the individual bondholder may be better off tendering. Meanwhile, the pari passu clause, broadly read, diminishes the credibility of the sovereign's nonpayment threat by expanding the class of possible ex post enforcement actions. This makes it more likely that the sovereign will offer a fair division of the surplus in the first place.

Of course, if the sovereign does make the fair offer of $\$ 70$, an opportunistic holdout can wield the pari passu clause, broadly read, in an attempt to get $\$ 100$. This disrupts the performance of the composition. But the sovereign is not without recourse. Under the drafting pattern common until recently, all it has to do is add to the offer an exit consent under which the pari passu clause

103 We see once more that with sovereign debt the distinction between "rank" and "payment" proves soft; "rank" has no meaning unless it determines payments. 
is removed from the old bonds. ${ }^{104}$ A majority creditor vote will suffice to remove it. ${ }^{105}$

\section{Summary}

Imagine an emerging-market financing closing in 1992 in New York. Counsel for the borrower appreciates the problems bound up in UACs and pari passu clauses, broadly read. So counsel drafts the bond contract with a CAC and a pari passu clause that explicitly states that it covers only contractual and positive law priorities and creates no rights with respect to disproportionate payments made after default. The reason, counsel explains, is to reduce frictions in a restructuring process that must follow in the wake of an external shock to the borrower's economy. Unfortunately, counsel explains, such a process would have to include the issue of bonds then in the process of creation.

The hypothetical seems incredible for two reasons. First, in 1992, it was in the interest of counsel's sovereign client for bond purchasers to proceed on the assumption that the 1980s-pattern exclusion of bonds from restructuring would continue to prevail. That assumption presumably impacted the rate of interest on the bonds in the borrower's favor. Secondly, seeking to change the standard form to rationalize its operation in the event of default would signal negative information about the borrower's creditworthiness, impacting the rate of interest on the bonds to the borrower's detriment.

To insist on the narrow meaning of pari passu today, now that the external shock has occurred and restructuring frictions matter more than the terms of the financing, arguably shifts a risk from the issuer back to the bondholder-a risk previously priced, allocated, and paid for.

\section{PARI PASSU AND BOND CONTRACT INTERPRETATION}

Part I set out the case for the narrow reading of pari passu, and the case for the broad reading followed in Part II. This Part works the conflicting discussions through the analytical framework of bond contract interpretation. This analysis proceeds in four stages: first, literal meaning; second, market understanding; third, drafting burden; and fourth, purpose interpretation. The

104 Alternatively, the pari passu clause can be rendered ineffective by an amendment of the waiver of sovereign immunity. See supra note 25.

105 Nothing need prevent the sovereign from doing the same thing with respect to the $\$ 50$ offer. 
matter can be determined and concluded at any stage, cutting off further inquiry.

\section{A. Stage One: Literal Meaning}

Contract interpretation starts with the literal word. The interpreter puts herself in the shoes of an ordinarily reasonable person, making assumptions respecting the reasonable person's usages and patterns of mind. ${ }^{106}$ This reasonable reader is assumed to employ standard English usage and interpret in accord with its generally prevailing meaning. ${ }^{107}$ Such objective literalism holds out advantages for the judicial decisionmaker: it is neutral and even-handed, and distances the judge from responsibility for the result. It also limits the set of evidentiary referents, simplifying adjudication. Objective literalism also holds out advantages for contract parties. Of course, the party to a complex contract never can know all of its literal implications; but literal interpretation imports stability (if not certainty) even so. The bias toward literalism applies with special strength in the interpretation of publicly traded debt. ${ }^{108}$ Bond contract forms are inspected repeatedly by experienced business lawyers who expect standard English usage to apply to their work. ${ }^{109}$ At the same time, literalism narrows the range of possible results, decreasing variance and thereby enhancing trading value. ${ }^{110}$

\section{The Meaning of "Pari Passu in Priority of Payment"}

How does the reasonable reader of English interpret the phrase "rank at least pari passu in priority of payment"? Professor Andreas Lowenfeld, in his declaration on behalf of Elliott in its action against Peru, argued for a literal interpretation as follows:

A number of articles have suggested that pari passu clauses, though very common in sovereign loan agreements, do not mean what they say, or cannot be relied upon by lenders if they are disregarded or violated by borrowers. ... I have no difficulty in understanding what the pari passu clause means: it means what it says-a given debt will rank equally with other debt of the borrower, whether that borrower

106 William W. Bratton, Jr., The Interpretation of Contracts Governing Corporate Debt Relationships, 5 CARDozo L. Rev. 371, 378 (1984).

107 RESTATEMENT (SECOND) OF CONTRACTS $\$ 202$ (3)(a) (1981).

108 See, e.g., Broad v. Rockwell Int'l Corp., 642 F.2d 929, 948-51 (5th Cir.) (en banc), cert. denied, 454 U.S. 965 (1981); Harris v. Union Elec. Co., 622 S.W.2d 239, 248 (Mo. Ct. App. 1981).

109 Bratton, supra note 106, at 379.

110 See Broad, 642 F.2d at 942-43. 
is an individual, a company, or a sovereign state. A borrower from Tom, Dick, and Harry can't say "I will pay Tom and Dick in full, and if there is anything left over l'll pay Harry." If there is not enough money to go around the borrower faced with a pari passu provision must pay all three of them on the same basis."

There is much to be said for Professor Lowenfeld's reading. Putting to one side the problem of Latin translation, the stress in the standard clause appears to lie on the word "payment" rather than on "priority." To a reasonable English reader, "priority" sweeps up a range of phenomena, including ordering in time, and the ordering of payments in time is what the broad reading seeks to regulate.

The literal words also admit the narrow reading, however. Its proponents move the stress to the words "rank" and "priority," arguing that the clause targets status in respect of payment rather than payment itself. " The problem is that the limitation, thus coaxed out of the literal words, does not make much sense in the abstract. This forces the proponents to follow up with an elaborate explanation of the salience of legal priority in the contracting context. ${ }^{113}$ There results a mandarin gloss, intelligible only by reference to generations of practice lore. Because the matter at bottom concerns the meaning attached by a bondholder rather than a bond lawyer, the narrow reading, while admitted by the language, cannot prevail in a contest limited to the literal word. It needs the further evidentiary support of a showing of market understanding.

The ensuing question is whether the broad reading, proposed as the literal meaning, carries such objective weight as to foreclose further reference to circumstance. Reference to circumstance can open the door to the conclusion that ambiguity forecloses a stage one literal interpretation. At this point in the analysis, the proponents of the narrow interpretation intervene successfully, making a more than adequate case identifying an ambiguity in the language. Once the contextual support for the narrow meaning is on the table, we see that the standard pari passu clause easily can be read in accordance with it, making a distinction between "rank in priority of payment," the status, and "payment," the event. This is just the sort of showing that underscores the shortcoming of aggressive literalism. Even as literalism holds out advantages,

111 Lowenfeld Declaration, supra note 1, TI1 11-12. For Professor Lowenfeld's updated Declaration, see Professor Andreas F. Lowenfeld, Declaration in the Matter of Cour d'Appel de Bruxelles, R.K. 240/03, La République de Nicaragua contre LNC Investments LLC et Euroclear Bank, S.A.C., Jan. 27, 2004.

112 See supra text accompanying notes 36-40.

113 See supra text accompanying notes $37-42$. 
if it precludes reference to context it can make things uncertain because particularized and ascertainable market understandings often apply. As a result, a door is held open for contracts, even bond contracts, to be read in context. ${ }^{114}$

At this point, the narrow reading's proponents make a literalist counterattack, based on the allocation of a burden of clarity. A careful drafter wanting to assure attachment of the broad meaning might have added a confirmatory reference to the act of payment: "pari passu in priority of payment ... and will be paid as such." 15 A minority of pari passu clauses take this additional step. ${ }^{116}$ The very existence of more specifically drafted clauses carrying the broad meaning suggests a distinction between the clause's two forms. Under this, bond contracts are sorted between those referring only to "priority of payment," which would take the narrow reading, and those making a further reference to the act of payment, which would take the broad reading. ${ }^{17}$

This ad hoc assignment of a burden of clarity does not, however, tell us the meaning of the clause-in-chief. A contract that adds "payment" to "priority of payment" does not by virtue of its own existence dictate the meaning of a contract that only mentions "priority of payment." All it tells us is that the drafter of the contract stating both phrases believes the form of the clause used more generally to be vaguely and inadequately drafted, something we already knew, and that that drafter wants to make sure the broad meaning attaches. We are still left trying to ascertain the meaning of the more common form of the clause. As to that, the phrase "priority of payment" unfortunately has no plain meaning that determines the choice between the broad and narrow interpretations. The sorting argument can win only at stage two or stage three. At stage two, a court applying New York law brings to bear a standard of market understanding, a standard that applies when publicly traded bonds are interpreted. $^{118}$ To sustain the posited distinction at this stage requires an

114 See RESTATEMENT (SECOND) OF CONTRACTS $\$ 202(1)$ (1981). For a bond case applying the rule, see Buchman v. American Foam Rubber Corp., 250 F. Supp. 60, 75 (S.D.N.Y. 1965).

115 Lee C. Buchheit, The Pari Passu Clause Sub Specie Aeternitatis, INT'L FIN. L. ReV., Dec. 1991 , at 12. Buchheit also offers an even more elaborately drafted clause. Id.; see also Wood, supra note 29, at 373 (arguing that a judge should not attach the broad meaning unless words like "equal payment" or "equal treatment" appear in the clause).

116 Italy's bonds provide an example: "We will pay amounts due on the debt securities equally and ratably with all general loan obligations of Italy." Supplement to Prospectus, US $\$ 3,000,000,000$ Republic of Italy 2.75\% Notes Due 2006 (June 16, 2003).

117 See Buchheit \& Pam, supra note 38, at 886-87; Gulati \& Klee, supra note 8, at 645.

118 Sharon Steel Corp. v. Chase Manhattan Bank, 691 F.2d 1039, 1048-51 (2d Cir. 1982), cert. denied, 460 U.S. 1012 (1983). 
evidentiary showing that the sovereign bond market actually distinguishes between contracts that do and do not expressly distinguish "priority of payment" and "payment." Alternatively, a burden of clarity could be imposed at stage three on a normative showing that the bondholders rather than the issuer should have made things clearer.

\section{Consistent Contracts, Counterfactuals, and Slippery Slopes}

Reasonable persons draft internally consistent documents. The tradition of literal interpretation accordingly rules that writings in a single transaction should be interpreted together and that an interpretation giving effective meaning to all terms of an agreement should prevail over an interpretation leaving a part with an unreasonable or ineffective meaning. ${ }^{119}$ Proponents of the narrow meaning contend that it leads to an internally consistent bond contract that operates in harmony with the wider structure of the sovereign's obligations, while the broad meaning creates inconsistency and disharmony.

\section{a. Other Obligations}

It is argued that the broad reading makes no sense because, applied literally, it prohibits the sovereign from making payments that everyone agrees have to be made. These include payments to international financial institutions (IFIs) like the $\mathrm{IMF}^{120}$ and to trade creditors who provide necessary goods and services-the police, the army, the hospitals, and the milkman. ${ }^{121}$

IFIs demand and receive de facto priority. Private creditors accept this because these last resort sources of credit tend to be beneficial. IMF bailout loans can even stave off default. ${ }^{122}$ And it is true that the pari passu clause would be better drafted if it excepted these loans explicitly. But that observation does not tell us how the clause applies to those loans. That the clause does not mention IFI payments does not mean it is intended to cover them, even though it literally could be read to cover them. Just about the only thing that is clear about the clause is that it is not, and never has been, scrupulously drafted. It follows that there is no reason to expect or demand scrupulousness respecting IFIs.

\footnotetext{
119 Restatement (SECOND) OF CONTRACTS $\$ \S 202(1)-(2), 203$ (a) (1981).

120 Gulati \& Klee, supra note 8, at 641.

121 Id.; Wood, supra note 29, at 373

122 Bratton \& Gulati, supra note 11.
} 
Coming at this point from another direction, assume that the broad meaning attaches. It does not follow that Elliott could use the clause to get a payment headed to the IMF enjoined, even in Belgium. A convention of IMF priority has prevailed in the market for a half century. ${ }^{123}$ Accordingly, under a market understanding of interpretation, the standard clause does not cover the payment to the IMF, and IFI payments can be excepted from the clause's reach at stage two. And even if there were no market understanding, it is not clear why Elliott would bother investing in the law suit-IFIs have broad immunities, ${ }^{124}$ so an attachment probably would not lie.

As to the police protection in the streets and milk for the children, the standard clause covers only "external indebtedness." This defined term tends to cover only obligations in respect of money borrowed from abroad. ${ }^{125}$ Neither trade credit (domestic or foreign) nor domestic obligations in respect of borrowed money are covered. Note that even if they were covered the promise would be effectively unenforceable because the only venues for catching such payments would be the sovereign's domestic courts. Short-term external borrowing facilities in support of trade for essential commodities would be covered, but such coverage falls within the clause's essential purpose: A sovereign that can trade as usual has a diminished incentive to restart payment. Meanwhile, the milkman can be paid.

\section{b. Counterfactual Possibilities}

If pari passu clauses are such good things under the broad reading, it is asked why corporate debt contracts omit them. If rank and payment are the same thing, must not Aunt Agatha refrain from paying the baker if she is ignoring the butcher? Why does the bar tab omit a pari passu clause? ${ }^{126}$

The reasons are twofold. First, before default, sovereign and private debt are similar-no one insists on pari passu payment because different obligations have different timetables and everyone's obligations are being serviced timely. Second, after default, sovereign and private debt are radically different. The bar owner, Aunt Agatha's butcher, and the corporate bondholder are remitted to action at law against the bar customer, Aunt Agatha, and the

23 Gelpern, supra note 15 , at 1122 .

124 Id. at 1120.

125 See, e.g., Prospectus Supplement to Prospectus, Government of Jamaica, 10.625\% Notes Due 2017, at 58-59 (June 4, 2002) (defining external indebtedness to cover funds "borrowed or raised including acceptances and leasing").

126 Buchheit \& Pam, supra note 38 , at $885-86$. 
corporate bond issuer, respectively. Given severe distress, the bankruptcy system provides a more user-friendly venue for enforcing equality and constraining preferential payments to favored creditors than would resort to a further action at law in the state courts under a pari passu clause. ${ }^{127}$ Sovereign creditors do not have these expedients, so their contracts include the pari passu clause as a second-best (or maybe third-best) solution.

But why, it is asked, if the broad meaning attaches, did not enforcing litigation occur earlier? After all, sovereign creditors have been receiving haircuts in painful restructuring negotiations for decades even as other classes of debt have been excepted, including, until recently, bonds. Because pari passu clauses have been ubiquitous in debt contracts throughout the period, if they were worth anything, someone should have gone to court to halt payments in violation. ${ }^{128}$

The answer to this question lies in the institutional differences between bank and bond-market lending. Members of bank lending groups operate under cooperative norms enforced by reputational and regulatory constraints. ${ }^{129}$ The normative framework includes, within the group, equal treatment. ${ }^{130}$ If de facto priorities allocated by the defaulting sovereign present a problem, group organization facilitates solution in the context of the restructuring negotiations themselves. As the source of funding shifted from the banks to the bond markets in the 1990s, observers warned that the days of gentlemanly cooperation were over. They predicted that with proliferating bondholding, litigation in the event of distress finally could be expected..$^{131}$ The prediction proved correct.

\section{c. Consistency}

The proponents of the narrow reading, appealing to the rule of consistency, point out that syndicated loan agreements usually contain a "sharing clause" as well as a pari passu clause. It is argued that if the pari passu clause is broadly read, these contracts cover the same function twice. If that is true, they argue, the broad meaning makes no sense, because the sharing clause is

127 See supra note 39.

128 Buchheit \& Pam, supra note 38 , at 884.

129 Buchheit, supra note 76, at 53-54.

130 See Buchheit \& Reisner, supra note 24, at 504-05.

131 Buchheit, supra note 76, at 54. 
exhaustively negotiated and drafted, although the pari passu clause is complete in a sentence. ${ }^{132}$

A number of responses can be made. First, belt-and-suspenders drafting is not unusual in financial contracting. Second, the question of interpretation arises in connection with bond contracts, not syndicated loan agreements. Given the long, chameleon-like history of the pari passu clause, there is every reason to suppose it might take on a different meaning in respect of a bond in 1995 than it had in respect of a 1975 bank credit facility, if only because in the case of the bond de facto priority was entertained as an active possibility. Third, the two clauses perform different functions. Sharing applies to the lenders, constraining potential enforcement actions by individual banks for the benefit of the other members of the lending group. The pari passu clause covers the borrower's voluntary payment activity rather than the lenders' enforcement activity, which by hypothesis puts the borrower in an involuntary posture. The pari passu clause also reaches outside of a given issue's group of holders to cover payments to all foreign private lenders. It also should be noted that bond contracts differ from bank loan agreements in not traditionally imposing sharing duties in respect of unilateral enforcement activity. ${ }^{133}$ With bonds, the private law norm of reward to the diligent creditor prevails. ${ }^{134}$ Thus sovereign bond contracts permit a holder to accelerate its own bonds unilaterally ${ }^{135}$ and private bond contracts permit a holder to sue individually for missed payments. ${ }^{136}$ There does not appear to be any inconsistency.

\section{d. The Slippery Slope}

It is suggested that the broad reading makes the pari passu clause a dangerous instrument-that it implies that all postdefault payments must be pro rata across all creditors, whether benefited by the clause or not, and that it

132 Buchheit \& Pam, supra note 38, at 884; see also Gulati \& Klee, supra note 8, at 646. Gulati and Klee also argue that the broad reading renders the negative pledge and acceleration clauses superfluous. I do not understand these connections. As to mandatory payment clauses and tumover clauses, see supra note 29.

133 When the official sector suggested sharing clauses in sovereign bonds in 1998, the investor community rejected it. Buchheit \& Pam, supra note 38, at 884-85.

134 I Thomas D. Crandall et al., The LaW of Debtors and Creditors $\$ \S 6.18,6.41$ (2002) (describing first-in-time priority to enforcing creditors); $2 \mathrm{id} . \S 16.10$ (noting that outside of the delimited bankruptcy recapture provision, preferential payments are not fraudulent conveyances and are not voidable).

135 See supra note 28.

136 Action by an indenture trustee of a private issue, in contrast, proceeds for the benefit of the group and is subject to a different set of rules. See REvisEd MODEL SIMPLIFIED INDENTURE $\$ \S 6.07,6.08$ (2000) (providing that holder can sue on its own bonds but that amounts collected by trustee be paid pro rata), reprinted in 55 BUS. LAW. 1115 (2000). 
further implies a lack of finality with respect to any non-pro rata payment received. A nonrecipient will have an action against the recipient of any nonpro rata payment. ${ }^{137}$

These are interesting but implausible interpretive speculations. The broad reading supports the bondholder interest because it forces the sovereign either to leave the bonds out of the restructuring or bring in all classes of debt similarly situated, and because as long as default continues, it requires that any payment made on foreign debt be made pro rata with respect to the debt covered by the clause. At no point does the benefited bondholder make a promise to reject or share a proffered payment not made pro rata; at no point do any other claimants make or receive promises respecting payments. It follows that no third party rights are created. It is difficult to imagine that a court would make these extensions, even as it goes without saying that vultures looking for deep pockets will assert third-party claims. ${ }^{138}$

The foregoing should not be taken to assert that pari passu clauses, broadly read, do not trigger difficult issues of application. They do, with the primary questions concerning particular applications of a pari passu payment concept. Assume that an exchange offer has closed, but that a holdout has procured a judgment for principal plus accrued interest. The issuer now is ready to make the first interest payment on the new bonds. What is pari passu treatment of the holdout who no longer holds a bond but a judgment? Does the payment of seven cents on the dollar on the new bonds mean the judgment creditor gets paid one hundred cents on the dollar of its judgment? The clause itself provides no answer.

\section{B. Stage Two: Market Understanding}

Proponents of the narrow interpretation contend that their reading has such currency in sovereign debt markets as to conclude the matter under the standard of market understanding. The narrow reading, they assert, embodies "the market's collective memory of where [the clauses] originated and what they were designed to achieve." 139 It is the "settled understanding" of

137 Buchheit \& Pam, supra note 38, at 885-86.

138 See Nacional Financiera, S.N.C. v. Chase Manhattan Bank, 2003 WL 1878415 (S.D.N.Y. Apr. 14, 2003) (holding that holder of debt covered by pari passu clause has no action against unrelated creditor receiving a payment in violation).

139 Buchheit \& Pam, supra note 38, at 918. 
practitioners in international debt markets, ${ }^{140}$ a meaning "accepted by general consensus among market participants." 141

The discussion in Part II, with its explanation of the broad meaning's economic functions, goes some distance in refuting this assertion because it considers the interest of the bondholder rather than the memory of the bond lawyer. Any remaining distance can be covered by a review of the legal commentary. At least one commentator clearly accepts the broad reading. ${ }^{142}$ The broad reading also at least appears to be within the contemplation of a leading treatise writer. ${ }^{143}$ Other discussants, ${ }^{144}$ including the Emerging Market Creditors Association (EMCA), ${ }^{145}$ recognize the existence of an active interpretive dispute and acknowledge that many lawyers, bankers, and bondholders subscribe to the broad reading. ${ }^{146}$ No less an authority than Lee Buchheit, advancing the narrow meaning as one for which a "good case" can be made, ${ }^{147}$ has acknowledged that opinions differ on the clause's meaning:

One sometimes encounters an inquisitive borrower who asks why this little breeze off the Tiber has ruffled through the pages of his loan agreement. This is when the fun starts. "It means you can't pay back somebody else's loan if you're not then current on your payments under this loan," is how some bankers may explain it. "It means you can't give a preference to some other creditor that you are not at the same time giving to us," will be the interpretation offered by others....

\footnotetext{
140 Wood, supra note 29, at 372.

141 Buchheit \& Pam, supra note 38 , at 889

142 Brian W. Semkow, Syndicating and Rescheduling International Financial Transactions: A Survey of
} the Legal Issues Encountered by Commercial Banks, 18 INT'L LAW. 869, 899 (1984).

143 Tudor John, supra note 40, at 96 ("[The clause] is intended to prevent the earmarking of revenues of the government towards a single creditor; the allocation of foreign currency reserves, and generally against legal measures which have the effect of preferring one set of creditors against the others or which discriminate between creditors."). The passage can be read either way. The mention of "allocation of foreign currency reserves" as a practice apparently separate from "earmarking" connotes a preferential payment. Id.

144 Reference also can be made to Alliance Bond Fund, Inc. v. Grupo Mexicano de Desarrollo, S.A., 143 F.3d 688 (2d Cir. 1998), rev'd, 527 U.S. 308 (1999). This case was litigated from the Southern District of New York through the Second Circuit to the Supreme Court and back on a preliminary remedies question. The right asserted was to payment under a pari passu clause. Although the issue of interpretation was not litigated, the parties in interest appear to have assumed that the broad reading attached.

145 Letter from Abigail McKenna on behalf of Board of Directors of EMCA, to Judge Thomas P. Griesa (Jan. 14, 2004) (on file with author) (stating that "there are conflicting views among leading market participants regarding the correct interpretation of the pari passu clause").

146 Buchheit, supra note 72, at 11, 12; Gulati \& Klee, supra note 8, at 645.

147 Buchheit, supra note 72, at 12. 
[T] he lender is not being told anything about where it will stand in a queue of bankruptcy creditors. In the absence of this explanation ... a goodly number of bankers (and more than a few sovereign borrowers) seem to believe that the pari passu covenant is there to compel the borrower to pay all of its external debt on a ratable basis (either in terms of the amount, or the timing, of debt service payments) ....

Finally, we turn to the trenches, where standard bond contract language has been redrafted in the past year or so. Actors working under G-7 auspices have devised new CACs adequate to the task assigned by the Treasury. ${ }^{149}$ Informal pressures have resulted in the insertion of these clauses in New York borrowings by Mexico, Brazil, Uruguay, South Africa, and many other countries. $^{150}$ The new CACs tend to permit amendment of payment terms on approval of seventy-five percent of the bondholders. ${ }^{151}$ The new forms also tie amendment or removal of their pari passu clauses to the seventy-five percent supermajority figure. ${ }^{152}$ Under earlier standard forms, pari passu clauses were not mentioned specifically in the UAC and arguably were subject to amendment or removal by a bondholder majority. ${ }^{153}$ Majority amendment makes the clauses more vulnerable to removal by exit consent. The inclusion of the pari passu clause in the territory covered by the new CAC supermajority provision looks like a giveback: Even as the UAC is abandoned, the pari passu clause gets more protection from removal in an exchange offer, being elevated to equal dignity with the bond's payment terms. If the drafters of the new CAC attached the narrow meaning of pari passu, this innovation would not make sense. Under the narrow meaning, the pari passu clause is only a boilerplate technicality - a covenant covering a residual class of borrower actions unlikely ever to implicate the value of the bonds. One would neither expect such a provision to be singled out for removal by exit consent nor to be protected by a supermajority amendment provision. The change in the contracting pattern signals strongly that contemporary drafters either attach the

\footnotetext{
148 Id. at $11,12$.

149 See Bratton \& Gulati, supra note 11.

150 John Barham, Cooking Up a New Solution, LATINFIN., June 2003, at 10. The list also includes Canada, Turkey, Belize, Guatemala, Panama, Venezuela, and Korea. One exception to the trend is Israel, which used UACs in its New York law registration. For a recent report on this front, see INT'L MONETARY FUND, PROGRESS REPORT TO THE INT'L MONETARY AND FIN. COMM. ON CRISIS RESOLUTION (2003), available at http://www.imf.org/external/np/pdr/cr/2003/eng/090503.pdf.

151 See Uruguay Exchange Offer, supra note 26, at 39.

$152 \mathrm{Id}$.

153 The matter is not free from doubt. See supra note 27 and accompanying text.
} 
broad meaning or deem likely its attachment by a court applying a standard of market understanding.

What the market understands, then, is that informed observers disagree about the clause's meaning and that the dispute must be resolved in court. Lawyerly precedents and practices do not of themselves dictate a case for the narrow meaning.

\section{Stage Three: Drafting Burden}

Should not the proponent of the broad meaning bear a burden of clarity? Or, alternatively, perhaps the borrower should bear the burden of clarity on the ground that the narrow meaning is counterintuitive. Courts often decide between disputed interpretations by assigning such a drafting burden. Once the burden is imposed, the case is decided against the party bearing the burden. This is an easy route to a decision and so is attractive to the court.

Where, in a case such as this, inquiry yields two plausible competing interpretations, contract law, as a last resort, ${ }^{154}$ allows the invocation of the canon of interpretation contra proferentem, or interpretation against the drafter. ${ }^{155}$ As counsel for the underwriters customarily drafts the bond contract, ${ }^{156}$ this implies a burden on the bondholders, the underwriters being the bondholders' predecessors in interest. Unfortunately, this approach lacks a basis in reality in this case. With old standard language like this, there is no drafter against which to construe.

If we were to go ahead anyway and allocate a drafting burden here, we would do so on the ground that a given party's drafter should have clarified the clause. But, as between the two parties to the sovereign debt contract, no persuasive distinction can be drawn that allocates this responsibility, whether based on culpability or capability. A question arises: Why, given this background of controversy, would expensive lawyers put such a vague clause in their contracts when a simple sentence would clarify matters? In fact, sometimes getting the deal closed is both sides' highest priority. Vaguely drafted clauses hold open a matter in dispute and avoid a negotiation standoff that could disrupt the transaction's accomplishment. ${ }^{157}$ As we have seen, a

\footnotetext{
1543 ARTHUR LINTON CORBIN, CORBIN ON CONTRACTS $\$ 559$ (1951).

155 See RESTATEMENT (SECOND) OF CONTRACTS $\$ 206$ (1981).

156 See Stephen Choi \& G. Mitu Gulati, Innovation in Boilerplate Contracts: An Empirical Examination of Sovereign Bonds, 53 EMORY L.J. 929, 990 (2004).

157 This is not uncommon in financial contracting. See Bratton, supra note 106, at 384-85.
} 
borrower's lawyer who insisted on a pari passu clause unambiguously expressing the narrow meaning could disrupt lender expectations respecting exclusion from restructuring and also could have been seen to signal hidden information about pending distress. ${ }^{158}$ A lender's lawyer seeking a clause unambiguously expressing the broad reading could disrupt things too, given the existence of a literature advocating the narrow reading and the tradition of sovereign discretion respecting payment priorities. With a drafting tradition going back decades and a market satisfied by a vaguely drafted clause, incentives lie with leaving well enough alone. The drafting lawyers and their clients consciously left the open question as to the meaning of pari passu to a reviewing judge.

The law and economics notion of a penalty default does not prove helpful either. Like the common law canon of interpretation against the drafter, the penalty default applies when one party to the contract has superior information and an incentive not to disclose it. ${ }^{159}$ The penalty default puts the burden of clarity on the party with the information advantage, prodding it to disclose. To import this notion into the sovereign debt context puts the burden on the borrower, for in a sovereign bond negotiation the borrower has superior information about its own financial health and intentions respecting priorities in the event of distress. But this is a crude route to an endorsement of the broad meaning. A more sustained interrogation of the economic context is needed.

Either proponent could have done a better job of drafting here. But neither has greater fault. As between the two proponents and their respective clients, there is no pertinent distinction that justifies allocation of an outcomedeterminative drafting burden.

\section{Stage Four: Conflicting Purposes and Comparative Expectations}

Sharon Steel Corp. v. Chase Manhattan Bank ${ }^{160}$ famously established a standard of market understanding in bond contract interpretation. The market understanding is to be applied as a matter of law, thus bypassing the jury as well as subjective particulars concerning the contracting parties and their

158 See supra Part II.C.

159 Ian Ayres \& Robert Gertner, Filling Gaps in Incomplete Contracts: An Economic Theory of Default Rules, 99 Y ALE L.J. 87, 127-30 (1989).

160691 F.2d 1039 (2d Cir.), cert. denied, 460 U.S. 1012 (1983). 
intentions. ${ }^{161}$ It tends to be forgotten, however, that the parties in Sharon Steel proved no market understanding sufficient to decide the case. The court instead balanced the interests at stake using a norm of least injury under uncertainty as to meaning:

Where contractual language seems designed to protect the interests of both parties and where conflicting interpretations are argued, the contract should be construed to sacrifice the principal interests of each party as little as possible. An interpretation which sacrifices a major interest of one of the parties while furthering only a marginal interest of the other should be rejected in favor of an interpretation which sacrifices marginal interests of both parties in order to protect their major concerns.

A similar approach will be required in the interpretation of the pari passu clause. As in Sharon Steel, the vagueness of the clause's language combines with the noisiness of the background signals from the market to put the onus on the judge. The case must be decided by reference to the purposes of the contract language, the expectations of the parties, and the values at stake.

Sharon Steel's norm of least injury is backward-looking-it focuses on existing contracts and the allocation of sunk costs among the parties to those contracts, without asking questions about future effects and incentives. Efficiency considerations usually dictate a forward-looking approach. Is Sharon Steel's norm by implication inefficient? No, because bond contract interpretation is a subject matter that tends to implicate only wealth allocation respecting past transactions. The future presents less reason for concern than usual in this context because the next generation of contracts always can be rewritten. Once a definitive New York law opinion has been rendered respecting pari passu, the interpretation it attaches becomes the focal point for the market's understanding. New bonds will be priced to reflect the attendant risks. If the market decides that the judicial reading does not suit its purposes, the drafters of future contracts can reverse the result by redrafting so as to reflect whatever meaning they wish to attach. Of course, path dependencies or other frictions could retard such an adjustment. ${ }^{163}$ But that worry does not seem cognizable here, given recent market movement toward CACs after a

161 See id. at 1048-51.

162 Id. at 1051.

163 For the view that network effects can retard the responsiveness of standard bond contract forms, see Marcel Kahan \& Michael Klausner, Standardization and Innovation in Corporate Contracting (or "The Economics of Boilerplate"), 83 VA. L. REV. 713 (1997). 
century's use of UACs. ${ }^{164}$ Accordingly, absent a showing that one reading is clearly superior to the other reading in respect to the future of the sovereign bond market, the judge safely can dispense with prospective implications and concentrate on the parties to the transaction in question and all similar past transactions.

As to existing contracts, the outcome will follow from the temporal perspective chosen, ex ante or ex post. An ex ante perspective favors the broad reading. Here the purposes of the parties are fixed as of the time of contracting, by hypothesis during the optimistic days of the early 1990s. At that time, as we have seen, the 1980 s restructuring pattern still signaled de facto priority treatment for bonds. Issuers took advantage of this impression and pari passu clauses figured into the illusion of priority. The contract price presumably reflected that expectation.

An ex post point of view situates expectations at the time of default, and, at least in the case of Argentina, recognizes the fact that restructuring implies daunting process barriers. The balance of interests arguably tips to the narrow interpretation. The primary original purpose-the assurance of the continuance of the 1980 s practice of excluding bonds from restructuring-has failed. There is simply too much bonded debt to allow its effectuation. That being the case, the bondholders' best interests lie in a smooth restructuring process. After all, a composition only succeeds if the debtor holds out a surplus (assuming the bondholders manage to organize). The broad reading makes possible after-the-fact disruption of the composition and, thus, interferes with the bondholder majority's pursuit of the surplus. Now, it is true that the broad reading also assists the bondholders as they bargain for the largest possible share of the surplus. But the bondholders are not without contractual assistance here, for all 1990s sovereign bond contracts issued in New York contain UACs.

The proponent of the broad reading is not without an argument at this stage: The threat of disruption may be overblown. Pakistan, Ecuador, and Ukraine show that sovereign debt restructurings can work in this bondholder era. ${ }^{165}$ Holdouts have not been a problem. Credible exchange offers have to put value on the table. Bondholders, including vultures, have tended to grab the value and have avoided costly enforcement actions. Furthermore, pari passu clauses are vulnerable to removal by exit consent. The vulture problem

\footnotetext{
164 See Choi \& Gulati, supra note 156 (describing these developments in detail).

165 See Chuham \& Sturzenegger, supra note 49, at 26-27.
} 
seems to concern not debt issues in recent compositions but old paper-either defaulted issues as to which no composition ever was attempted or issues subjected to restructuring prior to use of the exit consent device.

At no point in this analysis does the narrow reading attach because "priority of payment" means only legal priorities. The narrow reading commends itself on the assumption that it assists a bondholder majority in accessing a payment stream that is value-maximizing in the restructuring context. Payments are the only things that really count with sovereign debt.

\section{CONCLUSION}

Under this Article's interpretation of pari passu, a court legitimately can attach the narrow meaning, but only to the extent that it has been persuaded that process frictions pose an unduly costly barrier to sovereign debt restructuring and so attaches the narrow meaning as a means to the end of cost reduction.

An oddity in this interpretive approach must be admitted. It implies that pari passu meant one thing (broad reading) in a new issue of Argentine bonds in 1994 and another thing (narrow reading) in the same bonds in 2004, given default. It also implies that pari passu might revert to the broad meaning in a new sovereign issue containing a CAC that sweeps the pari passu clause into the supermajority amendment regime-as we have seen, this drafting development signals a preference for the broad reading. Although the meaning of the pari passu clause does have chameleon-like properties, this seems to go too far.

Interpretation that is dynamic over time makes perfect sense in this context. To see why, compare private debt contracting once again. With private debt, distress means bankruptcy, and one purpose of bankruptcy is to put most of the carefully drafted terms in the debtor's bond contracts into the paper shredder. Although the contracts are drafted with a view to debtor distress and are designed to protect the creditor's enforcement interest in the event of distress, they turn out to be value-destructive to both the debtor and the creditor when severe distress actually occurs. The result is a value-conserving intervention by the state in the form of a contract-avoiding bankruptcy regime. Economists are only beginning to articulate theories that explain the contradiction between 
the ex ante rational form of the debt contract and the same contract's ex post dysfunction. ${ }^{166}$

The point for present purposes is clear enough: The shift to the ex post in the interpretation of the pari passu clause follows from the fundamentals of the debtor creditor relationship. Where normally an ex ante timeframe should guide contract interpretation, so as to protect values freely allocated by the contracting parties from opportunistic ex post recapture, temporal perspectives work differently with debt, distress, and composition. Recognition of the tension between the ex ante and ex post creditor interest also helps explain why bond lawyers have for decades perpetuated a badly drafted clause. The problem continues with the new CACs. If a definitive judicial ruling attaches the narrow meaning, today's drafters face the problem of redrafting the pari passu clauses in the new CACs so as to make it clear that the broad meaning is intended. If they do that, however, they tie their own bondholders' hands in the event that severe distress makes composition a favored outcome and holdout disruption too costly.

The solution lies in a sovereign bankruptcy regime. The same economics that cause the pari passu clause to raise an intractable issue of contract interpretation demonstrate the bankruptcy of the U.S. Treasury's contractarian approach. There is no perfect debt contract that is efficient in bad times as well as in good.

166 See Emst-Ludwig von Thadden et al., Optimal Debt Design and the Role of Bankruptcy (Nov. 19, 2003) (unpublished manuscript), at http://papers.ssm.com/sol3/papers.cfm?abstract_id=44051. 
